Political Behavior manuscript No.

(will be inserted by the editor)

\title{
Is the left-right scale a valid measure of ideology?
}

Individual-level variation in associations with "left" and "right" and left-right self-placement

Authors: Paul Bauer, Pablo Barberá, Kathrin Ackermann, and Aaron Venetz

Accepted for publication at Political Behavior

\begin{abstract}
In order to measure ideology, political scientists heavily rely on the so-called left-right scale. Left and right are, however, abstract political concepts and may trigger different associations among respondents. If these associations vary systematically with other variables this may induce bias in the empirical study of ideology. We illustrate this problem using a unique survey that asked respondents open-ended questions regarding the meanings they attribute to the concepts "left" and "right". We assess and categorize this textual data using topic modeling techniques. Our analysis shows that variation in respondents' associations is systematically related to their self-placement on the left-right scale and also to variables such as education and respondents' cultural background (East vs. West Germany). Our findings indicate that the interpersonal comparability of the left-right scale across individuals is impaired. More generally, our study suggests that we need more research on how respondents interpret various abstract concepts that we regularly use in survey questions.
\end{abstract}

Keywords left-right scale $\cdot$ ideology $\cdot$ left $\cdot$ right $\cdot$ survey measurement $\cdot$ interpersonal comparability · measurement equivalence $\cdot$ concepts 


\section{Introduction}

In our daily life, we interpret, communicate, and understand the reality around us using a multitude of concepts such as "car", "breakfast", "time" and "friend" (Jaccard and Jacoby, 2010, 10ff.). Concepts like these normally trigger associations in our minds, and logically individuals may have different associations when they are faced with the same concept. When used in surveys, abstract concepts may have the effect that individuals "understand the 'same' questions in vastly different ways" (Brady, 1985, 271) and this leads to interpersonal in-comparability (also called differential item functioning, i.e. DIF) (Brady, 1985; King et al, 2004a). Another strand of literature refers to this problem as "measurement inequivalence".

A variety of previous studies have provided empirical evidence that different people associate different things with concepts that are used in survey questions, and that this affects their answers. Belson $(1981,182)$ probed respondents about the meaning of the question: "Do you think that children suffer any ill effects from watching programmes with violence in them, other than ordinary Westerns?" and found a "high degree of variability in the interpretation of terms like 'children', 'ill effects', 'violence',- such that respondents who offer identical choice of answer may well have been considering rather different aspects of the matter concerned" (Belson, 1981, 182). Clearly, respondents might not only offer identical answer choices but also different ones because of the variance in aspects they consider. ${ }^{1}$ The question "Do you think that most people can be trusted and that you can't be careful enough in dealing with people?" (Rosenberg, 1956) is widely-used to measure social trust. Uslaner $(2002,74)$ analyzed "think aloud" responses to this question and revealed a large variability in the associations with "most people". ${ }^{2}$ The use of this survey question may be problematic because different groups of people may attach different meanings to the concept "most people", and because respondents may think of different categories going from "unknown others" to "known others" (Sturgis and Smith, 2010, 89), which in turn impacts measurement values of trust. Braun et al $(2013,393)$ investigate peoples' associations when answering to the typical attitudinal questions on immigration that contain the concept "immigrants". In their study (only) a third of respondents thought of immigrants in general. In addition, respondents were more likely to consider immigrant groups that are visible in their country. The term "political" is another

\footnotetext{
1 In their seminal work "The Psychology of Survey Response" Tourangeau et al $(2000,45)$ dedicate a whole chapter to the general problem (see chapter 2.4.2) and discuss the study by Belson (1981). Belson (1981) reports that only 8\% understood the question as intended. Whereas some respondents associated "children" with "kids eight years old or younger", "others understood children as those 19-20 years old or younger" (Tourangeau et al, 2000, 45).

2 See the ANES 2000 pilot study open question on generalized trust. Uslaner (2002) finds that this question fares better than two other questions on fairness and helpfulness of Rosenberg's faith in people scale (Rosenberg, 1956).
} 
vague concept and people often disagree over what it signifies. Some people count few themes as "political" whereas others have a broader interpretation of the political sphere and, importantly, interpretation correlates with respondents' social and political attributes (Fitzgerald, 2013, 454). Finally, there is ample evidence that different individuals associate different things with the concept of "democracy" (Bratton, 2010; Bratton et al, 2004; Canache et al, 2001; Dalton et al, 2007).

Our study contributes to the existing literature in several ways. We investigate the interpretation of the concepts "left" and "right". The left-right scale is a standard question in most large scale comparative surveys such as the European Social Survey, the British Election Studies and the European Election Studies and has been used in hundreds if not thousands of studies, mostly in order to measure ideology. ${ }^{3}$ We examine (1) whether respondents have different associations with the concepts "left" and "right", (2) whether differences in associations may result in different measurement values in the left-right self-placement scale, and (3) whether these differences are systematically related to other variables and may interfere in relationships between these variables and the left-right scale. We conduct an empirical analysis using a unique data set from the German General Social Survey (ALLBUS 2008). For at least two reasons, the German case is substantially interesting and might provide relevant insights beyond the case itself. First, the political landscape in Germany is more complex than in other countries due to its political institutions. Most importantly, the multiparty system provides the voter with less clear-cut information on what left and right could stand for. Complexity is further increased by the federal organization of the state and the parties, due to that the regional chapters of the party slightly differ in their ideological orientation. Second, Germany has emerged out of two different states with two different political regimes. This allows us to test for some contextual variation in the associations with left and right. In this analysis, we apply topic modeling techniques to open-ended responses about the associations that respondents report having, when they encounter the concepts of "left" and "right". Thereby we link the literature on survey measurement and question interpretation and illustrate how these innovative methods in text analysis may be applied in future research (e.g. Roberts et al 2014b).

The next section presents our theoretical expectations and hypotheses. Section three outlines the data and the methods. Section four summarizes the empirical results. The paper ends with a discussion of our findings in Section five.

\footnotetext{
3 Google Ngram Viewer seems to indicate that widespread use really picked up in 1970 .
} 


\section{Theory and hypotheses}

Our theoretical framework builds upon the model of the survey response process as formulated by Tourangeau et al (2000). This model consists of four stages: comprehension, retrieval, judgment and response, with each stage comprising a different mental process (Tourangeau et al, 2000). During the first stage - the most relevant for this study - respondents link the key terms in a question to other concepts. In our application, these key terms would be the concepts "left" and "right" in the left-right question. Obviously, any concept - be it in a normal conversation or in a survey question - comes with a certain degree of vagueness, but some are more vague than others (Tourangeau et al, 2000, 45). Already a simple concept such as "car" may generate different associations among different individuals. ${ }^{4}$ However, in the social sciences we often query people's attitudes using much more abstract concepts such as "freedom", "justice", "democracy", "liberal", "conservative", "immigrants", "left" and "right". Individuals may have a wide variety of associations when encountering these abstract concepts. ${ }^{5}$ Importantly, some respondents may also have no associations at all, i.e. they are not able to attribute any meaning to a concept.

Respondents answer to "questions on the basis of whatever ideas are at the top of their heads at the moment of answering" (Zaller, 1992, 579). We will investigate the consequences of this response behavior using the example of the left-right scale. This measure is a very simple, popular, and widely-used scale that is supposed to capture one of the most important concepts in the social sciences, ideology. Due to its simplicity and brevity, it can be easily included in surveys without costing too much time or money. In Appendix A.1 we give an overview of the origin of the concepts "left" and "right", the use of the left-right scale to this date and the criticism it has received so far. As we will show the concepts "left" and "right" are abstract concepts that trigger a variety of associations. In surveys, respondents are however just asked to position themselves on a scale ranging from "left" to "right" without any further indication of what these concepts mean.

When people are asked, "In politics people sometimes talk of 'left' and 'right'. Using this card, where would you place yourself on this scale, where 0 means the left and 10 means the right?" (ESS 2012), they even face

\footnotetext{
4 Person A might have a small car in mind whereas person B might think of a Hummer which may affect their evaluation of e.g. the impact of cars on the environment.

5 It has long been argued that differences between scale points (e.g. the step from 9 to 10) may be interpreted differently by different respondents. Quantifiers on response scales such as "totally agree" also represent vague concepts and might be used differently by different respondents. For instance, Tourangeau et al $(2000,47)$ and King et al (2004a) discuss this problem and potential solutions. The problem we discuss here is similar in nature, however, we want to emphasize the role played by more abstract concepts such "democracy" or "left". Especially, in cross-cultural and cross-linguistic research the error induced by the latter concepts should be more relevant.
} 
two abstract concepts within one survey question. "Left" and "right" may mean very different things to different individuals (Bauer-Kaase, 2001; Freire and Belchior, 2011; Neundorf, 2009, 2011; Zechmeister, 2006). Some people might think of ideologies on an abstract level and even within this group of respondents the ideologies they have in mind might differ. For instance, "left" might be associated with communism or with socialism. Another group of people might think of specific values when being confronted with the left-right scale. Again, the values people think of potentially differ within this group. Relatedly, a pluralization of values correlated with "left" and "right" has taken place during the last decades (Knutsen, 1995). Some might associate "right" with order while others think of intolerance. Justice as well as freedom might be values typically connected to left. A third group of people might think of political positions on certain issues when asked about their own position on the scale. Since the policy space in Europe is at least two-dimensional (Kitschelt, 2004; Kitschelt and Hellemans, 1990), structured by an economic and a cultural dimension, the policy fields and issues individuals associate with each concept may differ. Person A might think of economic policies, person B might have social policies in mind, and person C might think of environmental topics. Finally a fourth group of people might connect the terms "left" and "right" with political parties and actors. Regarding the exact position of these actors, people might again differ. Some consider a more extreme left party to be "left" (e.g. Die Linke in Germany) while others name a more moderate party (e.g. SPD). Consequently, we expect that there is a strong variation in the associations respondents have with the concepts "left" and "right" (H1).

If respondents associate different things with "left" and "right" (H1) that could have an effect on measurement values on the left-right scale. In other words, the same individual (e.g. Peter) could give a different answer to the same survey question when he has a different association with the concept contained in that survey question, e.g. Peter associating "left" with "SPD" vs. "Communism" as depicted in Figure $1 .^{6}$ Depending on the extremity of the meanings attached to the terms "left" and "right", he might tend to position himself closer to the center of the scale or closer to its tails. Alternatively, it might simply depend on whether he associates ideologies, values or concrete policy issues with the left-right scale. For instance, left-wing values like equality have a positive connotation and might therefore lead to a more extreme position. Thus, we assume that respondents' associations with "left" and "right" influence them when placing themselves on the left-right scale (H2).

\footnotetext{
${ }^{6}$ We only illustrate the impact on measurement for different associations with "left". The same problem exists of course exists for "right" which is the other end of the scale.
} 
Moving to a two person example illustrates why H1 is so relevant. When we pick two respondents (Peter and

Fig. 1: Associations (e.g. with "left") and answers: Single individual (own illustration)

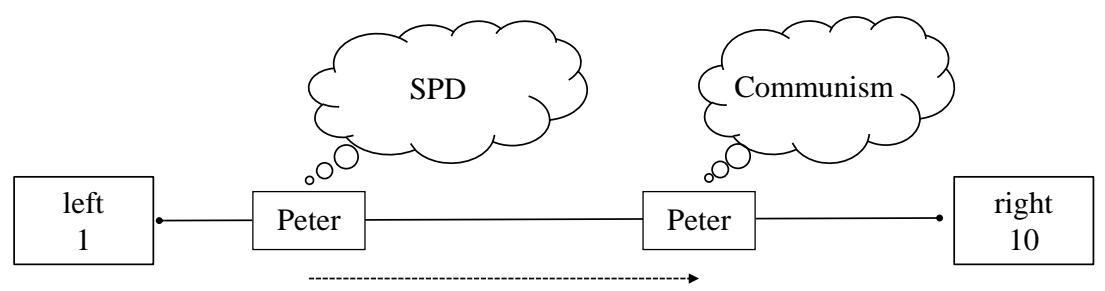

Hans) out of a sample, it could be the case that they have different associations with our abstract concepts. Consequently, if we compare their self-placement on the left-right scale and they are not on the same scale point, we cannot be sure whether this difference is due to variation in their associations with the concept "left" or due to a real difference in their political ideology (see Figure 2, assuming that both have the same association with right). In contrast, if the concept does trigger the same association for the two respondents, e.g. both Peter and Hans associate "left" with the Social Democratic Party, then we would know that the difference in their scale values is not due to a difference in associations with "left".

Individuals may have different associations, which may impact their measurement values. A further concern

Fig. 2: Associations (e.g. with "left") and answers: Two individuals (own illustration)

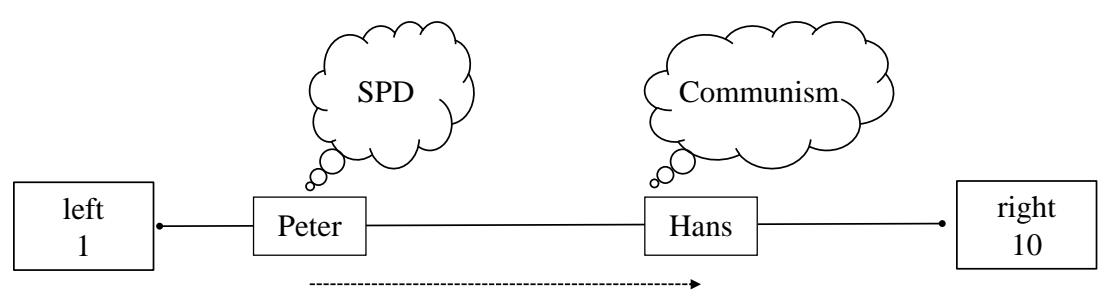

is, that these differences in associations could be systematically related to other variables. For instance, associations could depend on individual (or group) characteristics such as education, political interest or political sophistication (Bauer-Kaase, 2001; Freire and Belchior, 2011; Zechmeister and Corral, 2010). Such systematic co-variation could lead to biased estimates in analyses that use the left-right scale as explanatory or outcome variable.

The following example illustrates this problem: We might hypothesize that education affects ideology (e.g. Dunn 2011). We collect data on Hans - who has a college degree and places himself at 5 on the left-right scale 
- and on Peter who has only a high school degree and places himself further to the left at 3 on the left-right scale. From this data we could conclude that education negatively affects ideology, i.e. that the higher educated are more conservative ( $\uparrow$ education $\rightarrow \downarrow$ ideology). However, at the same time higher educated people might have associations that systematically differ from those of individuals with lower education levels.

Survey research indicates that a respondent's ability in terms of cognitive sophistication is a key factor explaining biased responses in population surveys (Krosnick, 1991). To understand and answer a survey question, a respondent needs to encode information included in the question and connect it to knowledge and information stored in her memory (Groves, 1989, 407-408). The errors produced on the different stages of this process are expected to be influenced by education because "the sophistication of the cognitive processing and the knowledge base of the respondent is a function of education." (Groves, 1989, 443). Studies, for instance, show that higher education reduces the likelihood of acquiescent and extreme responding (Meisenberg and Williams, 2008) and increases measurement reliability in surveys (Alwin and Krosnick, 1991). To sum up, education might serve as a proxy for cognitive sophistication and is expected to influence the understanding of and answering to survey questions.

Some with a college degree, for example, may think of ideologies such as "communism" instead of more concrete political objects such as "SPD" (Campbell et al 1960, 250-256, Converse 1964, 224-227, Inglehart and Klingemann 1976, 261, Fuchs and Klingemann 1990, 209, Klingemann and Wright 1973, Table 7). Let's assume that Hans associates "left" with communism whereas Peter associates "left" with SPD. Given that more extreme associations such as "communism" push respondents towards the middle of the scale, Hans's higher value on the left-right scale could then be a result of this difference in his association with "left". Consequently, we do not know whether education affects ideology directly or merely through the different associations it triggers within respondents.

Thus, as depicted in Figure 3 the explanatory variable (education) might affect the outcome variable (ideology). However, the mechanism could be that different levels of the explanatory variable trigger different associations, i.e. different levels of education trigger different associations with the concepts "left" and "right". ${ }^{7}$

\footnotetext{
7 This might also hold for politically interest or sophistication. More interested and sophisticated individuals are assumed to be aware of the multidimensionality of the policy space and the complexity of political problems. Therefore they might refer to abstract ideologies rather than to specific policy fields or the position of a specific party. It is also likely that partisans of different parties have different associations with "left" and "right" which might affect the relationship between partisanship and ideology as measured through left-right self-placement (see Inglehart and Klingemann 1976). For instance, supporters of left-wing parties might have more positive associations with "left" than supporters of right-wing parties.
} 
Overall we assume that respondents' associations with the concepts "left" and "right" are systematically related to individuals' characteristics such as education or political socialization that should affect the interpretation of abstract political concepts. Consequently, we hypothesize that associations respondents have with the concepts "left" and "right" are systematically related to respondents' characteristics which may affect observed relationships between these characteristics and the left-right scale/ideology $(\mathrm{H} 3)$.

To sum up, individuals or groups of individuals may have different associations with the concepts of "left" and

Fig. 3: Impact of differential associations on observed relationships (own illustration)

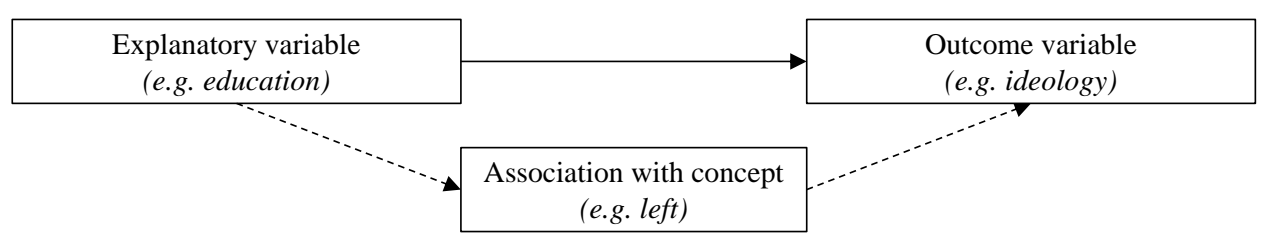

"right". This, in turn, may impact the measurement values on the left-right scale. If these associations vary systematically with other characteristics of individuals (e.g. socio-economic, linguistic or cultural background), it may lead to interpersonal incomparability and, thus, affect our findings when we investigate relationships between ideology and other variables.

We refrained from discussing a potentially more serious problem: Some populations or subgroups may not have any associations with abstract concepts (e.g. Fitzgerald et al 2011, 570) such as "left" and "right" at all. This could be an additional mechanism that undermines the validity of questions containing abstract concepts, as we'll carefully argue below. ${ }^{89}$

\section{Data and methods}

We use data comes from the General Social Survey 2008 in Germany (GESIS, 2011, 2009), which comprises 3469 individuals, and was collected through a two-stage disproportionate random sample in Western Germany (incl. West Berlin) and Eastern Germany (incl. East Berlin). The target population comprises all individuals (German and non-German) who resided in private households on the day of the interview and were born

\footnotetext{
8 As we will see below a large percentage of respondents did not give any associations with "left" and "right" when being probed in our study.

9 In terms of overall validity it is clear that a survey question should match a researcher's conceptual definition (Sturgis and Smith, 2010,89 ). The problems of interpersonal incomparability discussed here may, however, render a seemingly valid measure of a scientific concept invalid.
} 
before 1 January $1990 .^{10}$

The position on the 10-point left-right scale was measured as follows: "Many people use the terms "left" and "right" to denote different political attitudes. Here we have a scale that runs from left to right. When you think of your own political views where would you position yourself on this scale?" Directly after this question respondents were asked two questions (randomized order): "Would you please tell me what you associate with the term "left"?" and "Would you please tell me what you associate with the term "right"?" (Scholz and Züll 2012, Züll and Scholz 2012, Züll et al 2010, 5). Interviewers were told to note the exact responses. Hence, a probing strategy was employed in which respondents are asked follow-up questions. This "open-ended" technique is advantageous because by giving respondents a closed-ended question with categories (e.g. ideologies, parties) we would prime them with associations that they might not have had themselves. Since the probing questions were asked directly after the actual left-right question we assume that they really reveal the associations respondents had while answering. In standard interviews in which respondents are required to successively answer many questions in limited time, only one association may be immediately available in memory so that respondents answer on the basis of a single "top-of-the-head" consideration (Zaller 1992, 586, Taylor and Fiske). The probing technique above should capture this consideration. ${ }^{11}$

The result is textual data that contains respondents' separate answers to the two questions mentioned above. We treat and analyze the raw textual data in two different ways. First, we directly analyze the words mentioned by the respondents to examine the frequency with which different words have been used by respondents.

Second, to summarize respondents' answers into broader categories we rely on a topic modeling technique similar to Latent Dirichlet Allocation (Blei et al, 2003) which allows us to discover cluster of words that cooccur in subjects' responses to the question what associations they have with "left" and "right". This family of models considers each response as a distribution of different topics, and each topic as a distribution over words. Given the short length of the text in the responses, we estimate a Sparse Additive Generative (SAGE) model (Eisenstein et al, 2011), which has been shown to yield more semantically coherent topics than LDA

\footnotetext{
10 In the first sample stage municipalities (Gemeinden) in Western Germany and municipalities in Eastern Germany were selected with a probability proportional to their number of adult residents; in the second sample stage individual persons were selected at random from the municipal registers of residents. Targeted individuals who did not have adequate knowledge of German to conduct the interview were treated as systematic unit non-responses. The method of data collection were personal interviews with standardized questionnaire (CAPI - Computer Assisted Personal Interviewing) (see http://www.gesis .org/en/allbus/study-profiles/2008/ (12/28/2015)).

11 A different approach would be to query their associations before letting them locate themselves on the left-right scale. However, here we want to investigate, how respondents, deal with the left-right scale, and thus we consider this question order to be more adequate for that purpose. Another technique to reveal associations during the answering process could be the think aloud technique. Note, however, that this method comes with certain weaknesses suggested by Tourangeau et al (2000, 44-45).
} 
in these situations. The key difference is that SAGE models treat topics as distributions over deviations from a general distribution over words, and therefore prevents overfitting, which can be a problematic issue when many words are rare. We estimated SAGE models with different numbers of topics, using the implementation in the stm package for R (Roberts et al, 2014a). Subsequently, we evaluated their semantic coherence and exclusiveness independently from each other ( 4 raters) and concluded that 4 topics is the adequate number. Table 1 lists the top 10 scoring words associated with each topic, ordered by their "lift" (Taddy, 2013), which allows us to identify what words are more specific for each individual topic. For both concepts, we find that each topic identifies a theoretically relevant category. Political parties (SPD and greens on the left; CDU, CSU and FDP on the right) and ideologies (communism on the left; national socialism on the right) are associated with both concepts. "left" is furthermore linked to social values (equality and social justice) and policy aims (human rights and redistribution), while "right" is linked to right-wing extremists (nazis and radicals) and xenophobic attitudes (xenophobia and nationalism). For each topic a variable is generated that contains probabilities for each respondent that his or her answer belongs to this topic. Once we have computed the probabilities that each individual associated the concepts of "left" and "right" with each of these 4 different topics, we then test our different hypotheses. Importantly, since we are lumping together respondents into fewer broader higher-level categories, we lose variance in associations and ours is a conservative approach to the question being studied (in Appendix A.2 we elaborate on that point).

As a robustness check and validation tool, we check whether the results are comparable to analyses done using a classical manual coding strategy (See Section A.2 of the Appendix). In addition, the ALLBUS 2008 comprises different questions querying respondents' socio-demographic characteristics such as gender, education, income, age and other variables such as political interest and party preferences. Table 3 gives an overview of all variables used in the analysis. We apply various methods from simply counting words to estimating simple statistical models to test our hypotheses. 
Table 1: Top scoring words associated with each topic, and English translations)
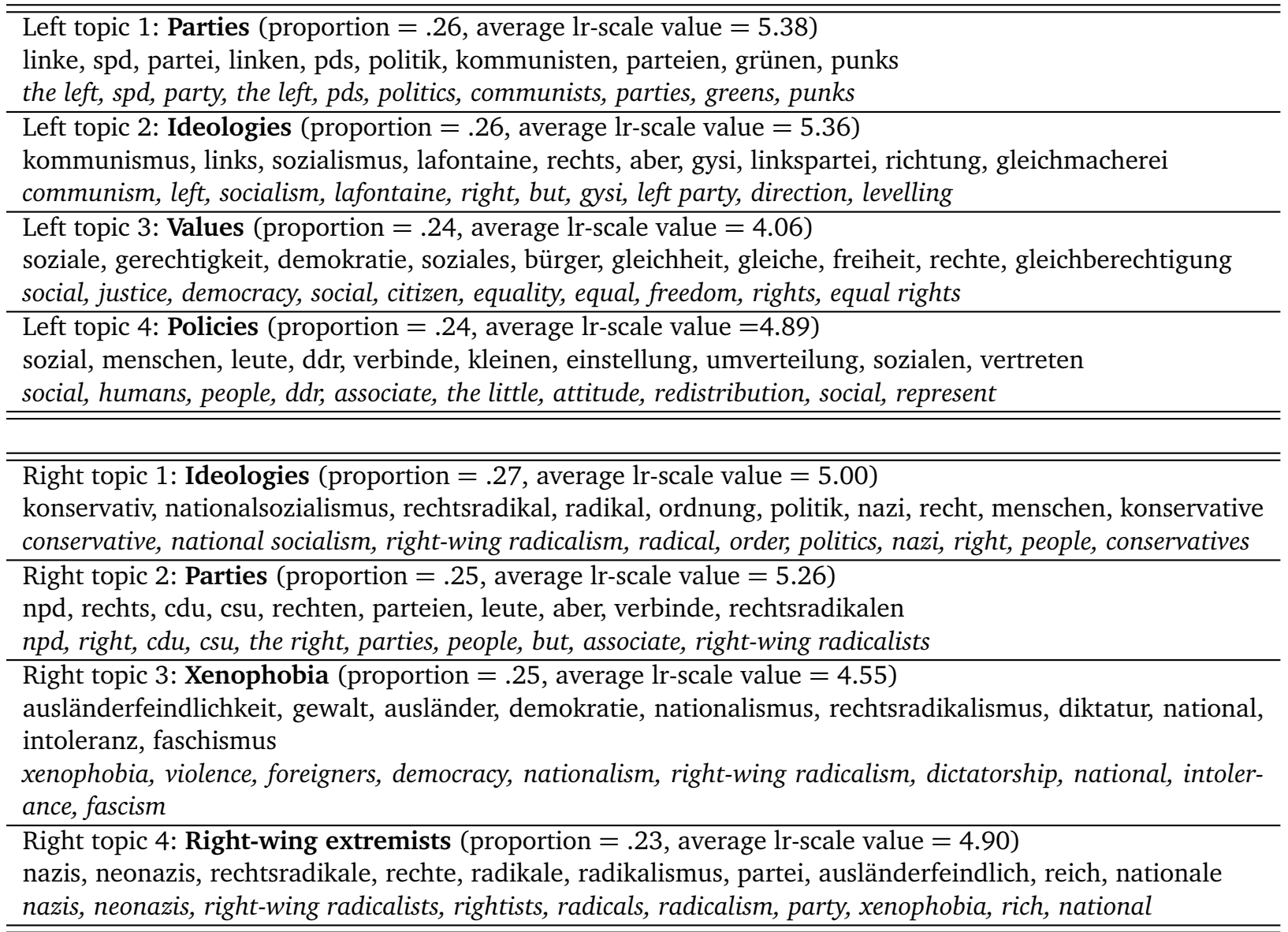

Note: "proportion" indicates the average estimated probability that any given response is assigned to a topic. "average lr-scale value" is the mean position on the left-right scale (from 0 to 10) of individuals whose highest probability belongs to that particular topic.

\section{Empirical results}

\section{Variation in associations with "left" and "right"}

First, we hypothesized that there is strong variation in the associations people have with vague concepts i.e. the concepts "left" and "right" (H1). To start, 21\% (713) gave no response at all to the probing question for "left" and $19 \%$ (664) gave no response at all to the probing question for "right" (17\% gave no response to both of the probing questions). Scholz and Züll (2012) analyzed non-respondents in this data set and conclude that non-response is linked to education, political interest and political activities. We assume that respondents would give an answer if they could to please the interviewer. If they don't it means that they do not have any clear associations with the concepts "left" and "right". Of those respondents who gave a response, 6\% (195) directly indicated that they "don't know" for "left" and 5\% (177) for "right". Hence, the overall share of 
respondents who do not give an answer regarding their associations lies at $27 \%$ for "left" and $24 \%$ for "right" (and 21\% for both probing questions). Those who can't (or do not) answer to both probing questions have a higher average (5.6 compared to 5) and a lower variance (2.4 compared to 3.1 ) on the left-right scale. ${ }^{12}$ Generally, if respondents do not comprehend the key concepts in a question they should not be able to decide what their attitude is (Zaller, 1992, 582). The gap between higher ability to answer fixed-choice questions and lower ability to do the same for more open formats was already revealed by Hochschild (1986). Overall, this seems to indicate that the question is too difficult for many respondents.

Figure 4 shows the words that were mentioned more frequently in relation to "left" (in red) and "right" (in

Fig. 4: Words that are associated with "left" and "right" (size $\propto$ word count)

\section{Words that are associated with "left"}

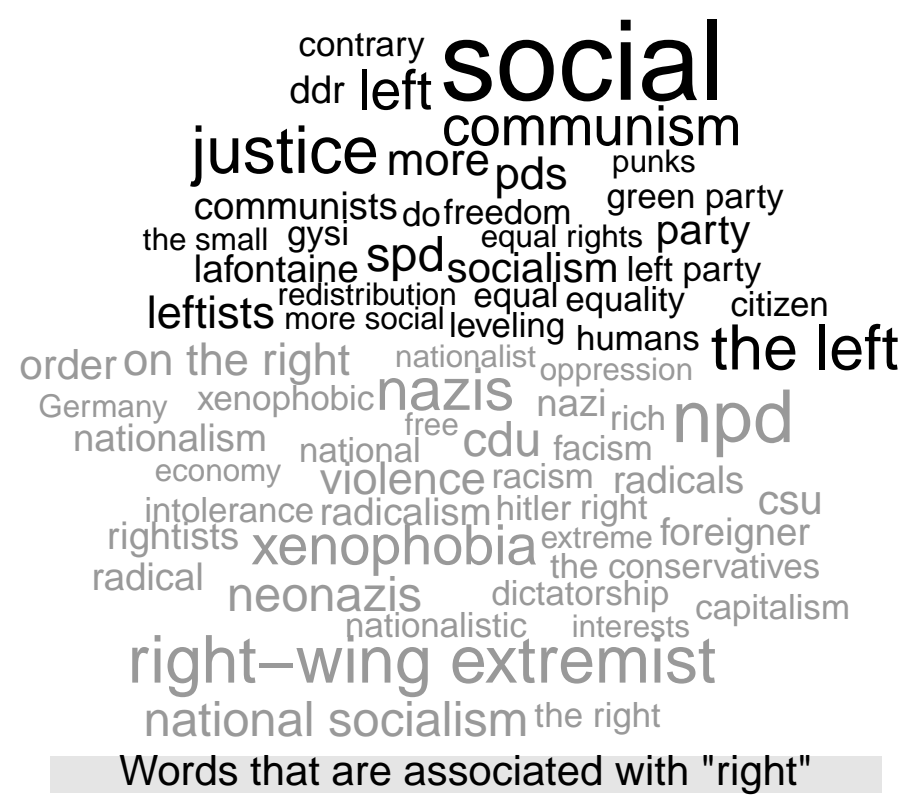

Note: Plot depicts most common words (size proportional to times mentioned) for both left (red) and right (blue). Some words appear several times because the english translation corresponds to several German terms such as xenophobia to Ausländerfeindlichkeit and Fremdenfeindlichkeit.

blue) (see Figure 14 for the original, in German). The size of the words is proportional to the times they were mentioned by respondents. It becomes immediately clear that the concepts "left" and "right" trigger a wide variety of associations going from ideologies, values to political actors such as the CDU, SPD or NPD to specific

\footnotetext{
12 In additional analyses (not reported here) we investigated the missings (don't know, no information) for a set of more concrete closed-ended policy questions in the same survey. The number of missings seems to increase with the difficulty of the question. Morever, don't knows regarding associations with left/right seem to predict those missings, albeit the effects are not very strong.
} 
groups such as right-wing extremists. Reassuringly, those respondents that respond to the probing questions clearly seem to make a difference between the abstract concepts "left" and "right".

In Figure 5 we turn from simple word counts to the answers as coded into the four topics with help of the topic model. Each individual gets four probability values indicating the probability of his or her answer being located in the respective topic. We divide individuals into the four categories, classifying them according to the topic for which they display the highest probability. Figure 5 displays the absolute numbers of individuals sorted into each topic. We can see that most answers tend to be located in the topic of political parties for left, followed by ideologies, values and policies. For right the most common topic is ideologies, followed by parties, right-wing extremists and xenophobia.

To sum up, there is strong variation in what respondents associate with the concepts "left" and "right". This is the case both when analyzing single words but also when coding respondents' answers into broader categories, which lends support to our first hypothesis (H1). "Strong variation" is a vague quantifier. But we hope that readers largely agree with us in the light of Figure 4 and 5. Importantly, both figures summarize and aggregate even stronger underlying variation in the data.

Fig. 5: Number of respondents in 4 different topics (split for "left" and "right" associations)
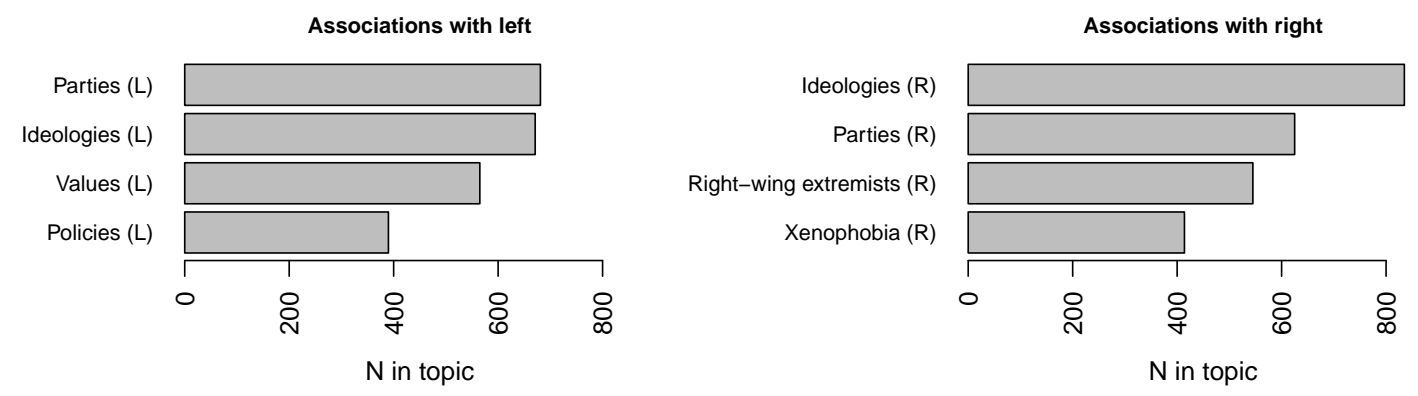

\section{Associations with "left" and "right" and measurement values on the left-right scale}

There is strong variation in respondents' associations with "left" and "right". This could become a significant problem if, as we hypothesize, measurement values on the left-right scale are to some extent dependent on respondents' associations with "left" and "right" (H2). We start by comparing means of respondent groups - grouped according to the category of their associations. Figure 6 displays the left-right scale means of 
respondents for categories of associations with "left". We see that there are some significant differences. Respondents whose answers belong to the topics "values" or "policies" have scale values that are lower on average in comparison to respondents whose associations belong to the topics "ideology" or "parties" (see Figure 6). Figure 7 is the same but for "right". In the case of "right" we can see that respondent who associate "right" with Xenophobia locate themselves further to the left than the other categories. ${ }^{13}$

Eventually, we are interested in whether these differences remain significant (i.e. are robust to) when we

Fig. 6: Left-right scale means for different subsamples of associations with left (dashed = sample mean, bars $=95 \%$ Cis $)$

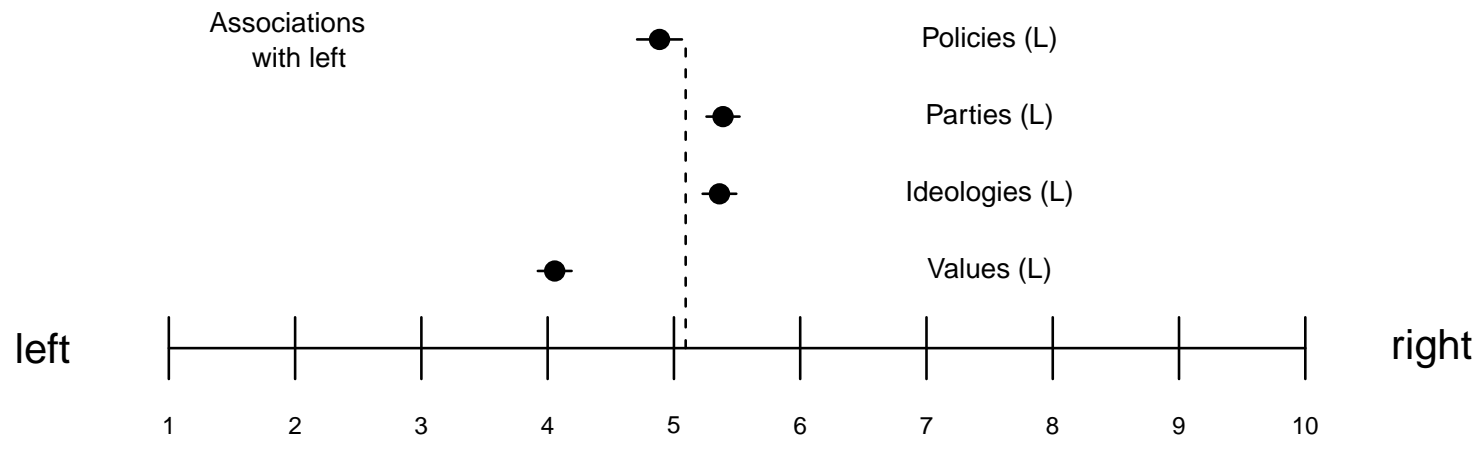

Fig. 7: Left-right scale means for different subsamples of associations with right (dashed $=$ sample mean, bars $=95 \%$ Cis)

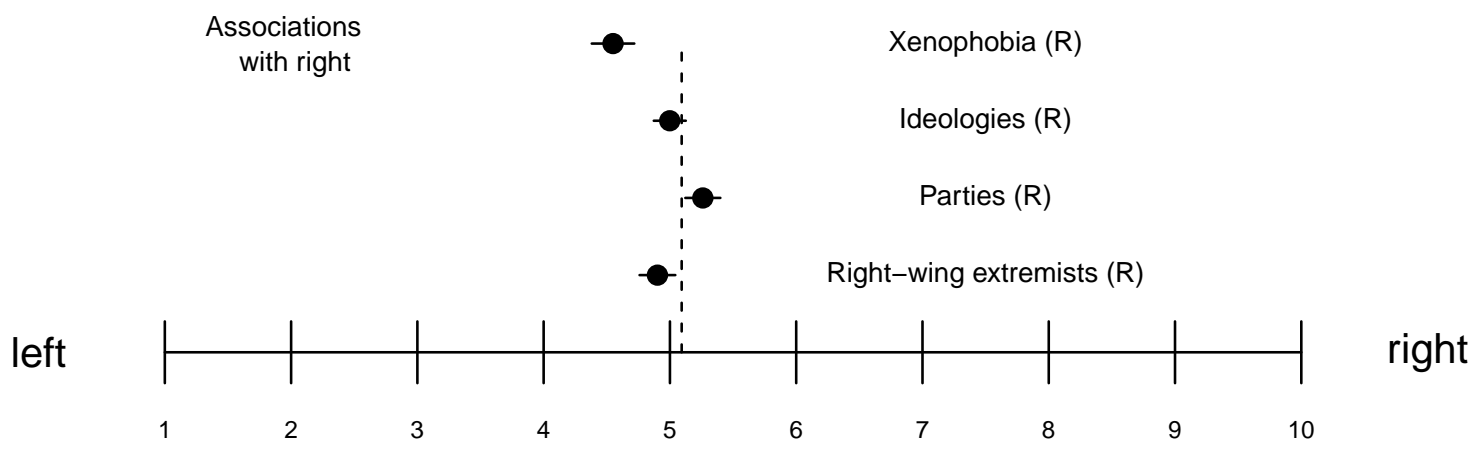

control for different co-variates that might influence both associations and ideology. For instance, support for a left wing party may affect both the associations one has with the concept "left" in the left-right scale as

13 As we demonstrate in Figures 15 and 16 in the Appendix, these results also hold even if we do not rely on this topic modeling technique and use instead simple word counts. This analysis shows that individuals located on different extremes of the left-right scale associate very different words to describe these two concepts. To facilitate reading these figures, in Table 4 we provide the top 10 words on each extreme of the $\mathrm{x}$-axis that were mentioned 5 or more times. 
well as the self-location on the left-right scale. We estimate two regression models in which the four topics of associations are introduced as a categorical variable (baseline is "values" for both categories) and the dependent variable is respondents' self-placement on the left-right scale. Model 1 in Figure 8 displays the results for categories of associations with "left" and Model 2 the results for categories of associations with "right" (see Table 5 for results). We control for gender (male), age, education, income, political interest, region of interview (east vs. west) and party preference (baseline $=c d u$ ). The results in Figure 8 provide evidence that associations do matter. Despite controlling for possible confounders that might influence both associations as well as ideology, associations do play a role of their own even if aggregated into large categories such as "Parties".

In additional models (see Table 6 and Table 7 in the appendix) we test the effect of "left" (or right) associations

Fig. 8: Linear regression of left-right scale measurement values on topics (categories) of associations
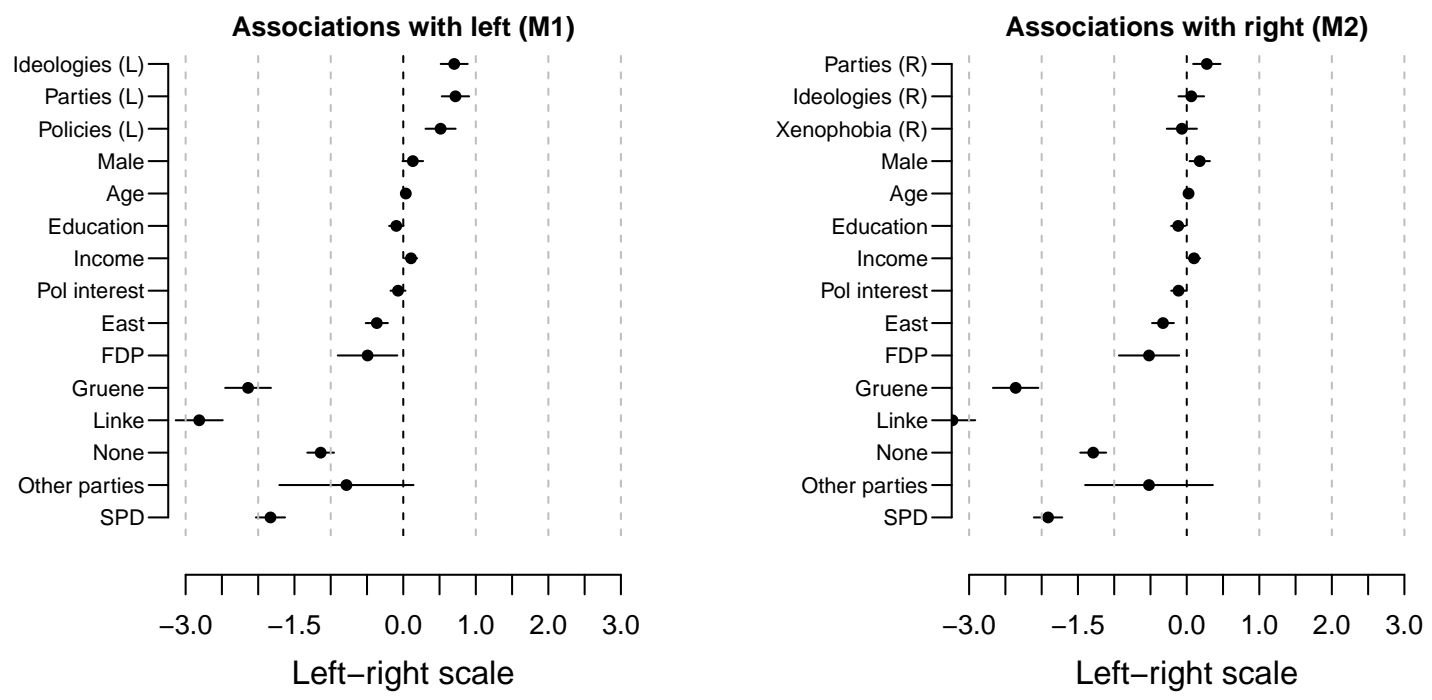

Note: Each line indicates a 95\% confidence interval, dots the coefficient of two different regressions of left-right self-placement on topic categories controlling for covariates. Both associations (= topics) and party preference have been introduced as categorical variables (baseline: values (left) /right-wing extremists (right) and cdu).

while holding the category of associations with the other scale point constant. We re-estimate Model 1 and Model 2 in the respective 8 sub samples, one model for each of the 4 topics that the other scale endpoint might be categorized into. We find effects on self-placement even when holding constant associations with the other scale endpoint.

Since we summarize associations into 8 broad categories we lose variation that might be responsible for even bigger differences in measurement values on the left-right scale. In this regard the results in Figure 11 
and Figure 12 in the Appendix, where we provide the estimated averages in the left-right scale of subgroups using a more disaggregated categorization, provide additional evidence in support of this hypothesis. In other words, the data suggest that measurement values on the left-right scale are related to peoples' associations with "left" and "right" (H2). Clearly, we rely on observational data and therefore have to be careful in making any causal interpretations. However, in our view the fact that this relationship holds even after controlling for the most important determinants of ideology should raise concerns. We use the conclusion/discussion to point towards potential experimental designs that may allow for further testing this relationship. ${ }^{14}$

\section{Systematic relationship with socio-demographics and potential impact on relationships}

Our third hypothesis states that associations respondents have with the concepts "left" and "right" are systematically related to respondents' characteristics which may affect observed relationships between these characteristics and the left-right scale/ideology (H3). We test this third hypothesis expanding our analysis in the previous section. Following the literature, we expect that proxies of sophistication such as education and political culture represented though western/eastern origin in the German context are important factors. In contrast, we would expect that variables such as gender or age matter less or not at all.

To examine whether that is indeed the case, we run eight different regressions of "topic usage" (the estimated probabilities for each individual, rescaled to a 0 to 100 scale) on five different sociodemographic variables of interest. We find that higher educated respondents tend to associate "left" more often with values and less so with parties (see Figure 9). The higher educated also tend to associate "right" more with ideologies and less so with parties although the effects are less strong. Not surprisingly, there is also a difference between East and West German respondents. Respondents from Eastern Germany tend to associate "left" more with values and less so with ideologies or parties. Moreover, respondents from Eastern Germany clearly associate "right" with xenophobia or right-wing extremists rather than with ideologies. These latter findings seem to fit well with the different past and present political realities in West and Eastern Germany. In contrast, effects for age, gender and income are largely absent.

In a second step, we investigate whether associations interact with education in shaping ideology. Both theory and empirical research suggest that there is a link (Ekehammar et al, 1987; Gabennesch, 1972; Gerber et al,

\footnotetext{
14 Preliminary analyses (without controls) not reported here but included in the replication files seem to indicate that associations with left and right are also linked to party left-right placements.
} 
Fig. 9: Systematic relationship between associations with "left" and "right" and characteristics of respondents

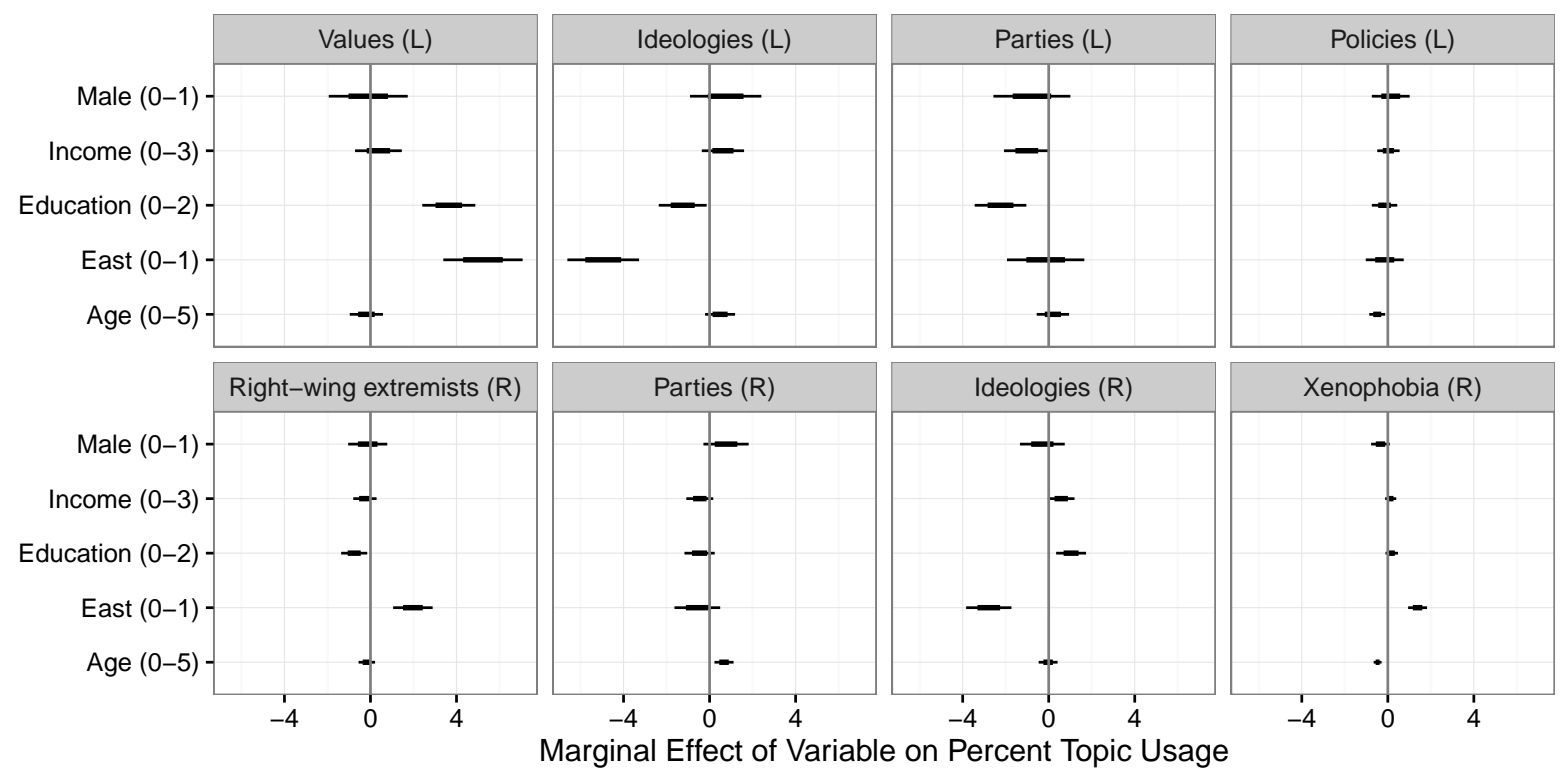

Note: Each line indicates a 95\% confidence interval (and 66\% confidence interval in darker color) for the coefficient of eight different regressions of topic usage (in a scale from 0 to 100) at the respondent level on seven individual-level characteristics. The line on the bottom right corner (second row, second plot), for example, shows that individual a one-category change in age is associated with around one percentage point increase in the probability that the individual associated "right" with political parties.

2010; Kaiser and Lilly, 1975; McClintock and Turner, 1962; Morton et al, 2011; Weil, 1985). But research also shows that education is linked to the ability of forming consistent ideological beliefs (Converse, 1964) and to response behavior and question interpretation in general (Tourangeau et al, 2000, 47-48). We showed that respondents of differing educational levels differ systematically with regard to their associations with "left" and "right" (see Figure 9). Building on that, we estimate six models in total for "left" and "right" (the sample comprises respondents that gave answers to the probing questions): Two bi-variate models, two models where we add the categorical topic variable as control and two models where we interact the categorical topic variable with education. Thereby, we examine whether the relationship between education and left-right self-placement is moderated by the association an individual has with left and right. A significant interaction term would indicate that the relationship of education and left-right self-placement is dependent on the association an individual has in mind and should therefore be treated with caution. Table 2 displays the results. For associations with "left" we find that adding them to the equation decreases the coefficient. In other words, the education-ideology relationship is weaker when controlling for associations with "left". Besides, education interacts with the topic "policies", i.e. in this subsample the negative relationship between education and ideology is stronger. For "right" the picture is somewhat different. Controlling for associations only slightly 
reduces the coefficient. However, when adding interactions we see that the negative relationship between education and ideology is stronger among those that associate "right" with xenophobia or ideologies. This last analysis provides some initial evidence that associations might very well play a role when investigating relationships between substantive variables (e.g. education) and the left-right scale (ideology).

Table 2: The effect of education on left-right self-placement and interaction with associations

\begin{tabular}{|c|c|c|c|c|c|c|}
\hline & \multicolumn{6}{|c|}{ Dependent variable: } \\
\hline & \multicolumn{6}{|c|}{ Left-right scale } \\
\hline & $(1)$ & $(2)$ & (3) & $(4)$ & (5) & $(6)$ \\
\hline Education & $\begin{array}{c}-0.29^{* * *} \\
(0.05)\end{array}$ & $\begin{array}{c}-0.20^{* * *} \\
(0.05)\end{array}$ & $\begin{array}{l}-0.14 \\
(0.10)\end{array}$ & $\begin{array}{c}-0.30^{* * * *} \\
(0.05)\end{array}$ & $\begin{array}{c}-0.28^{* * * *} \\
(0.05)\end{array}$ & $\begin{array}{l}-0.11 \\
(0.10)\end{array}$ \\
\hline Ideologies (L) & & $\begin{array}{c}1.27^{* * * *} \\
(0.10)\end{array}$ & $\begin{array}{l}1.29^{* * * *} \\
(0.16)\end{array}$ & & & \\
\hline Parties (L) & & $\begin{array}{l}1.28^{* * * *} \\
(0.10)\end{array}$ & $\begin{array}{c}1.31^{\text {**** }} \\
(0.16)\end{array}$ & & & \\
\hline Policies (L) & & $\begin{array}{c}0.81^{* * * *} \\
(0.11)\end{array}$ & $\begin{array}{c}1.07^{\text {*** }} \\
(0.19)\end{array}$ & & & \\
\hline Education * Ideologies (L) & & & $\begin{array}{l}-0.01 \\
(0.13)\end{array}$ & & & \\
\hline Education * Parties (L) & & & $\begin{array}{l}-0.02 \\
(0.13)\end{array}$ & & & \\
\hline Education * Policies (L) & & & $\begin{array}{c}-0.26^{*} \\
(0.15)\end{array}$ & & & \\
\hline Parties (R) & & & & & $\begin{array}{l}0.35^{* * * *} \\
(0.11)\end{array}$ & $\begin{array}{c}0.49^{* * * *} \\
(0.16)\end{array}$ \\
\hline Ideologies (R) & & & & & $\begin{array}{c}0.14 \\
(0.10)\end{array}$ & $\begin{array}{l}0.34^{* *} \\
(0.15)\end{array}$ \\
\hline Xenophobia (R) & & & & & $\begin{array}{c}-0.29^{* *} \\
(0.12)\end{array}$ & $\begin{array}{l}-0.01 \\
(0.19)\end{array}$ \\
\hline Education * Parties (R) & & & & & & $\begin{array}{l}-0.16 \\
(0.14)\end{array}$ \\
\hline Education * Ideologies (R) & & & & & & $\begin{array}{c}-0.22^{*} \\
(0.13)\end{array}$ \\
\hline Education * Xenophobia (R) & & & & & & $\begin{array}{c}-0.29^{*} \\
(0.16)\end{array}$ \\
\hline Constant & $\begin{array}{l}5.24^{* * * *} \\
(0.06) \\
\end{array}$ & $\begin{array}{l}4.27^{* * * *} \\
(0.09) \\
\end{array}$ & $\begin{array}{c}4.21^{* * * *} \\
(0.13) \\
\end{array}$ & $\begin{array}{l}5.25^{* * *} \\
(0.06) \\
\end{array}$ & $\begin{array}{l}5.15^{* * *} \\
(0.09) \\
\end{array}$ & $\begin{array}{l}5.00^{* * * *} \\
(0.12) \\
\end{array}$ \\
\hline Observations & 2,199 & 2,199 & 2,199 & 2,292 & 2,292 & 2,292 \\
\hline $\mathrm{R}^{2}$ & 0.02 & 0.10 & 0.11 & 0.02 & 0.03 & 0.03 \\
\hline Adjusted $\mathrm{R}^{2}$ & 0.02 & 0.10 & 0.10 & 0.02 & 0.03 & 0.03 \\
\hline
\end{tabular}

Note: ${ }^{*} \mathrm{p}<0.1 ;{ }^{* *} \mathrm{p}<0.05 ;{ }^{* * *} \mathrm{p}<0.01 ;$ Estimation using OLS; Dependent variable: Left-right scale;

\section{Discussion and conclusion}

This study investigates three hypotheses: First, that there is strong variation in respondents' associations with the abstract concepts "left" and "right" (H1). Second, that left-right measurement values are affected by respondents' associations (H2). Third, that associations are systematically related to respondents' characteristics and may, thus, affect relationships that we typically observe (H3). Using a unique survey from Germany we find empirical evidence in support of these hypotheses.

In line with earlier research our study challenges the left-right scale as a measure of ideology. However, the main innovation in this article in comparison to former studies that principally analyzed correlations between 
left-right and other attitude scales, is our analysis of open-ended responses using topic modeling techniques. The concepts "left" and "right", it seems, are too abstract for many. Respondents give an answer to the leftright self-placement question but when asked to specify what they associate with these concepts a significant share does not respond (cp. Scholz and Züll 2012). Those that do report associations, report a wide variety. These associations seem to affect self-placement on the left-right scale and are linked to other variables, such as education, which might lead to biased results in the study of ideology. Nonetheless, our study only represents a first step and provides multiple venues for future research.

First, just as others before we rely on observational data. While we believe that the format of our probing questions prevents such effects, some respondents' may feel inclined to report associations that are aligned with their earlier positioning on the left-right scale. One possible survey experiment that could address this concern would consist in priming respondents with associations, and then measuring how these primes affect their subsequent answers to the left-right self-placement question. However, this research design also has at least two significant shortcomings: By priming respondents with associations, respondents get artificial associations, i.e. associations that they did not have themselves. For instance, someone who might normally associate the term "left" with the SPD might suddenly end up associating it with the idea of equality. Moreover, such a priming experiment would artificially inflate the number of people that have any associations with the concepts at all. Keeping these caveats in mind, researchers should nonetheless pursue this strategy. Second, our data come from a single country at a single point in time. This limitation is mainly caused by data availability. The analysis presented in this article places high demands on the data including probing question on the meaning of left and right. The data necessary for a cross-national comparison is not available. We would, however, expect similar results in other countries and the differences should be apparent not only within other countries but also between different countries. The differences in the associations between the Eastern or Western part of Germany indicate that the associations might not only depend on individual but also on contextual factors. Therefore, we expect that a cross-national comparison would reveal even more severe problems with the scale than the analysis of a single country. Similarly, we would expect that the findings are partly bound to time. The overall historical context (e.g. period of the cold war compared to today) as well as changes in the political landscape (e.g. the emergence of a new party like the AfD in Germany) might change the meaning of left and right. Against the backdrop of these shortcomings, we argue that the 
German case is interesting and relevant for the analysis due to its complex political landscape and the historical emergence out of two different states. Third, one could argue that both left-right associations as well as left-right self-placements are affected by a respondent's "latent ideology". For instance, rightists on this latent scale might offer positive terms such as freedom and liberty for the concept "right" and place themselves more to the right on the left-right scale. In the present study we simply introduced various controls such as party preference, income etc. that serve as proxies for such a latent ideology. However, future studies may try to model this idea directly. Fourth, additional insights may be won by constructing a better measure of ideology from policy preferences and investigating how this measure relates to left-right self-placement as well as associations with the concepts "left" and "right".

Readers may wonder what other potential solutions there are to measuring ideology. A first solution - as just described - is to rely on more specific, less abstract questions/concepts to construct an ideological index based on their aggregation. Everett (2013), for instance, presents a scale for measuring conservatism using a feeling thermometer that could serve as a role model for the development of alternative scales. It could be combined with advanced scaling techniques such as item response theory models that became increasingly popular in political science literature (see e.g. Bafumi and Herron 2010; Jessee 2009). Fortunately, more and more surveys include such questions (including those mentioned in the introduction) albeit not necessarily over time. A second possible solution would be the usage of measures based on behavior that can be observed unobtrusively (Bonica, 2013; Kosinski et al, 2013). Third, the extensive literature on the Aldrich-McKelvey scaling method also provides solutions to mitigate interpersonal in-comparability (see e.g. Aldrich and McKelvey, 1977; Poole, 1998; Hare et al, 2015), which could also be complemented with the use of anchoring vignettes (see e.g. Bakker et al, 2014b,a; King and Wand, 2007; King et al, 2004b). When these alternative approaches are not accessible because of budget, data or technical constraints, researchers should make their assumptions explicit and discuss in their analysis to what extent interpersonal incomparability of the left-right scale could affect the validity of their results.

Finally, what we describe in this paper could be the tip of an iceberg. Potentially it may apply to many abstract concepts such as "democracy", "conservative", "liberal", "libertarian", "postmaterialist", "traditional", "authoritarian", and "immigrants". We tried to give an example of how we may investigate these issues in the future. Thereby, we used recently developed text-as-data methods to categorize the responses to open-ended 
probing questions and we contribute to a growing literature that relies on topic modeling techniques to examine open-ended answers (Roberts et al, 2014b). However, more research is necessary in order to understand what methods fare best with what kind of textual data and open-ended questions. 


\section{A Appendix}

\section{A.1 History and usage of the left-right scale}

The two concepts, "left" and "right", are used as description of the political space measured by a scale contrasting liberal or progressive with conservative political positions. They originate from the seating arrangement in the French Parliament (Fuhse, 2004; Raschke, 1998). Right after the French Revolution the Members of Parliament started to sit next to each other according to their ideological position: the conservatives sat on the right side, the progressives sat on the left side. This is how we began to associate these two simple adjectives of spatial positions and directions with political ideologies. From the very start, distinguishing between "left" and "right" has thus been a means to reduce the complexity of the political space, "which serves primarily to provide an orientation function for individuals and a communications function for the political system" (Fuchs and Klingemann, 1990, 205).

The first step towards measuring ideologies on a one-dimensional scale was made by the economist Hotelling (1929) who analyzed effects of the distance between the relevant market actors on the market price of a good. Taking up this concept of a spatial market, Downs (1957) developed the idea of a one-dimensional political market in which the whole spectrum of political preferences is "[...] ordered from left to right in a manner agreed upon by all voters" (Downs, 1957, 115). His political spatial market ranged from 0 to 100, covering the degree to which percentage the government should intervene in economic affairs which made his model the first to be based on a liberal-conservative scale, ranging from left to right. The liberal-conservative scale is the Anglo-American counterpart to the Western European left-right scale and they are theoretically very similar (and practically often treated as the same) (see Fuchs and Klingemann 1990, 204, Huber 1989, 601, Inglehart and Klingemann 1976, 244, Neundorf 2011, 233, Poole and Rosenthal 2007, Stokes $1963,368)$.

In current social science research the left-right scale is widely-used to measure respondents' ideology as well as to position political actors and parties. ${ }^{15}$ The response scales used in these publications differ widely. While some use three- to eleven-point scales, others forgo a neutral middle point and apply scales with an even number of scale points. Even though the vast majority of these articles trusts in the explanatory power of the scale, we are, of course, not the first social scientists to be suspicious of the left-right scale. There are a number of studies mainly focusing on the variance of interpretations of this scale (Bauer-Kaase, 2001; Conover and Feldman, 1981; Corbetta et al, 2009; Freire, 2006; Freire and Belchior, 2011; Fuchs and Klingemann, 1990; Inglehart and Klingemann, 1976; Jahn, 2011; Klingemann, 1972, 1979; Knutsen, 1995; Leonisio and Strijbis, 2014; Neundorf, 2009, 2011; Piurko et al, 2011; Rudi, 2010; Schmitt and van der Eijk, 2009; Vries et al, 2013; Zechmeister, 2006). With the exception of Corbetta et al (2009) and - to some extent - Rudi (2010), all of them report difficulties with the scale. Schmitt and van der Eijk (2009), Jahn (2011) and Vries et al (2013) for example show that the issue preferences or policy orientations associated with "left" and "right" differ across countries and within countries over time. Differences in the party polarization might be one explanation for different interpretations across countries (Freire, 2006). Regarding differences within a country, Freire and Belchior (2011) find that the interpretations of Portuguese citizens concerning "left" and "right" lack clarity and structure. Zechmeister (2006) comes to the same conclusion for Mexico and Argentina. Regarding Germany, Neundorf $(2009,2011)$ concludes that there has been a considerable increase in the diversity of understandings of "left" and "right" over time

\footnotetext{
15 Importantly, however, our results also matter for questions that ask respondents' to locate others (such as parties) on the left-right scale.
} 
that is the concepts lost clarity and became more and more vague. The study of Weber (2011) uses another approach by assessing the measurement equivalence using two different wordings of the question within one survey. According to her results, group means of self-placement on the scale are comparable among different countries, while relationships to other variables are not. We build our study on these former analyses dealing with potential problems of the left-right scale.

\section{A.2 Validation using the dictionary by Züll, Scholz and Schmitt (2010)}

We relied on topic models to analyze respondents' answers. A different approach would have consisted on employing the the dictionary (based on manual coding) developed by Züll et al (2010) to automatically code respondents' answers into different categories based on the their answers. This dictionary currently comprises a total of 7814 phrases, full words or parts of words and can be applied to any raw text data containing associations with "left" and "right". It was developed with the aim of allowing cross-time and cross-country comparisons of interpretations of the left-right scale. Their general scheme draws on earlier similar work by Fuchs and Klingemann (1989, 1990) and Bauer-Kaase (2001) and comprises eight broad categories into which respondents' answers can be coded: Ideologies, general social values, specific social values, social change (comprising forms, characteristics and means of social change), social groups, political actors, concrete aspects and affective evaluations (Züll and Scholz, 2012, 7-16). However, prior to coding answers into these eight categories, answers are coded into the 270 categories that are derived from an empirical "atheoretical" coding stage. In other words respondents' answers are coded into about 270 subcategories into which answers or parts of respondents' answers are sorted (see Züll and Scholz 2012, p.7-16 for the subcategories).

Any categorizing of open responses into fewer dimensions be it manually or automatically lumps together respondents. Generally, the fewer the lumping categories the higher the variance within the categories. As a consequence, groups are blurred, as is their distinctiveness and as a consequence there impact of their distinctiveness on e.g. left-right self-placement. While we prefer a model driven approach that avoids human error, we want to ensure that the general conclusions of our empirical analysis are not largely due to our approach of categorizing data with the topic models. Therefore we carry out additional analyses using the dictionary. In particular, besides using the topic model we also analyzed respondents' answers after they have been coded into the 270 different categories included in the left-right dictionary devised by Züll and Scholz (2012).

Figure 10 displays absolute numbers of respondents in the most common categories for both "left" and "right". Most respondents associate "left" with either values (solidarity, justice), ideologies (communism, socialism), parties (left party, SPD) or some political figure (politicians). The picture for "right" is similar with many people mentioning ideologies or values (national socialism, right wing radicalism, conservatism, patriotism), parties (NPD, DVU, republicans) but then also descriptions such as xenophobic or radical. Importantly, Figure 10 only displays the 10 most frequent categories.

In addition we compare means for respondents whose associations belong into one of the most frequent categories. Figure 11 displays the left-right scale means of those respondents whose answers were in the 11 most mentioned subcategories for "left". Figure 12 is the same but for "right". The sample mean is indicated by the dashed line. Just as for our previous categorization into 4 topics throughout the study we can see here that left-right measurement values differ for groups of respondents whose answers have been coded into categories using the dictionary. Groups that associate "left" with values such as equality, justice or solidarity display measurement values that lean 
Fig. 10: Most common categories of associations as coded with the dictionary
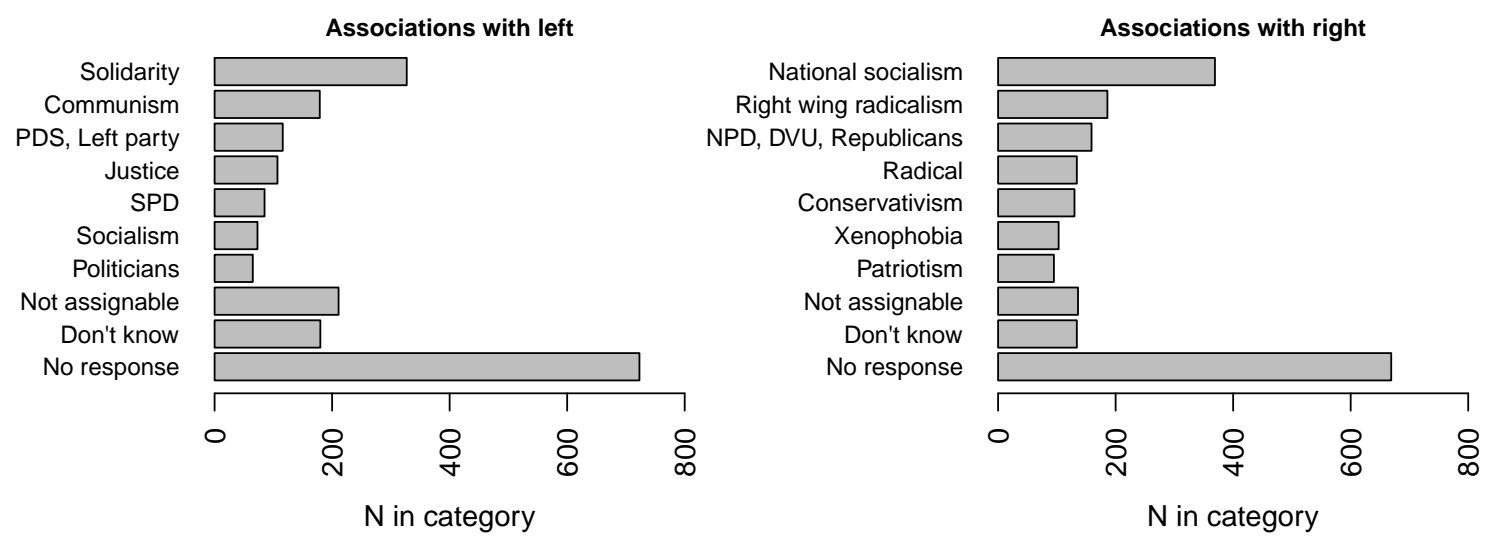

to the left. In contrast, groups that associate "left" with real socialism, with radicals or with communism display measurement values that lean to the right. Groups that associated "right" with national socialism, xenophobia or violence display measurement values that lean to the left. Importantly, these associations are highly consistent with our findings when we employ the four categories discovered by our topic model. In sum, these additional analyses seem to confirm our main conclusions, namely that there is considerable variation in the associations and that this variation may impact measurement values.

Fig. 11: Left-right scale means for 11 most common categories of associations with "left" (dashed = sample mean)

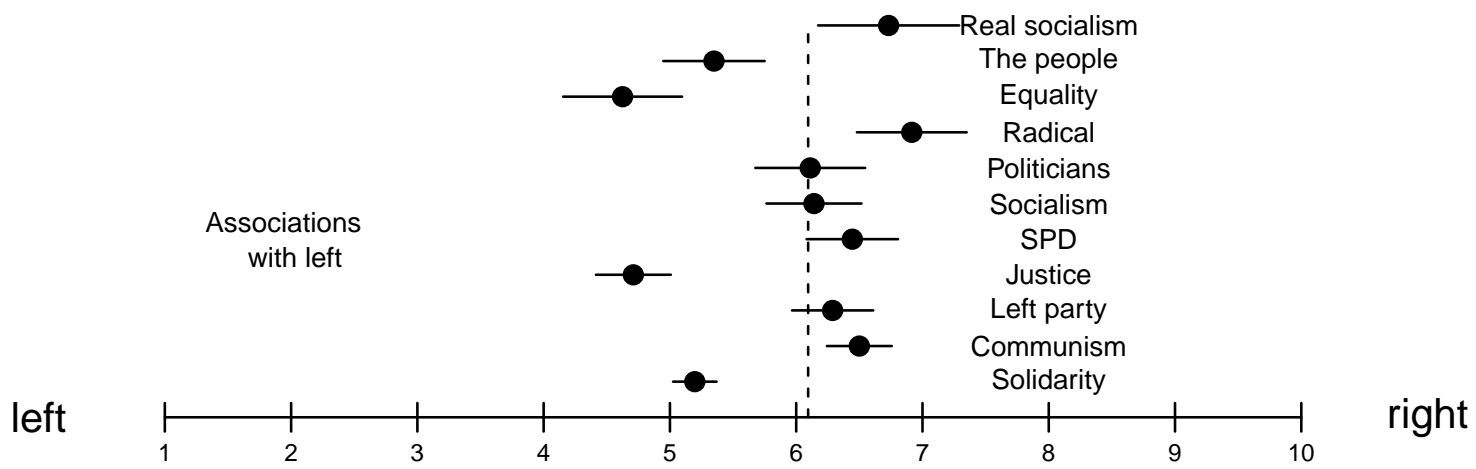


Fig. 12: Left-right scale means for 11 most common categories of associations with "right" (dashed = sample mean)

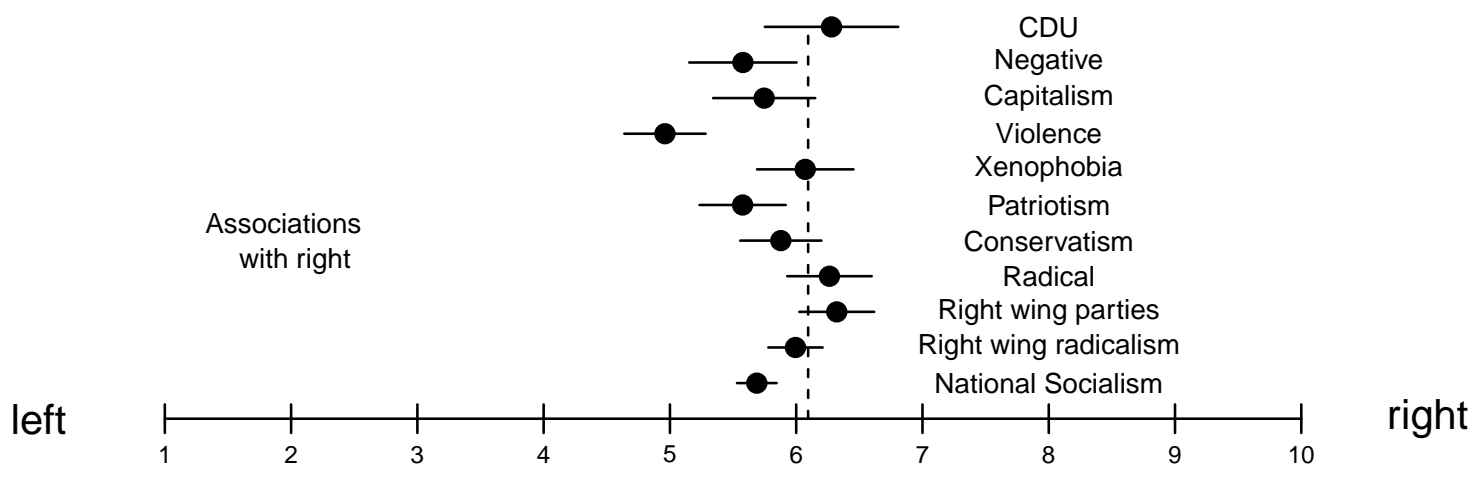

Fig. 13: Question wording in Allbus 2008 (see Scholz and Züll 2012, 1420)

Many people use the terms "left" and "right" when they want to describe different political views.

$\Rightarrow \quad$ INT.: $\quad$ Please display scale 28 and leave displayed until question F031.

Here we have a scale which runs from left to right. Thinking of your own political views, where would you place these on this scale?

Please select one of the boxes and name the letter indicated beneath it.

Left

Right

$\begin{array}{llllllllll}O & O & O & O & O & O & O & O & O & O \\ F & A & M & O & G & Z & E & Y & I & P\end{array}$

Could you tell me what you associate with the term "left"?

$\Rightarrow$ INT.: $\quad$ Record the response given precisely!

And could you tell me what you associate with the term "right"?

$\Rightarrow$ INT.: $\quad$ Record the response given precisely!

Table 3: Summary statistics

\begin{tabular}{|c|c|c|c|c|c|c|}
\hline variable & 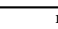 & mean & $\mathrm{s}$ & $\min$ & $\max$ & range \\
\hline Education & 3422 & 0.84 & 0.77 & 0 & 2 & 2 \\
\hline Age & 3457 & 1.88 & 1.21 & 0 & 5 & 5 \\
\hline East & 3469 & 0.31 & 0.46 & 0 & 1 & 1 \\
\hline Male & 3469 & 0.49 & 0.5 & 0 & 1 & 1 \\
\hline Political interest & 3469 & 1.06 & 0.76 & 0 & 9 & 9 \\
\hline Income & 3075 & 0.77 & 0.88 & 0 & 3 & 3 \\
\hline T1: Values (L) & 2307 & 0.24 & $\begin{array}{l}0.00 \\
0.2\end{array}$ & 0 & 1 & 1 \\
\hline T2: Ideologies (L) & 2307 & 0.26 & 0.18 & 0 & 1 & 1 \\
\hline T3: Parties (L) & 2307 & 0.26 & 0.19 & 0 & 1 & 1 \\
\hline T4: Policies (L) & 2307 & 0.24 & 0.09 & 0 & 1 & 1 \\
\hline T1: Ideologies (R) & 2419 & 0.23 & 0.1 & 0 & 1 & 1 \\
\hline T2: Parties (R) & 2419 & 0.25 & 0.11 & 0 & 1 & 1 \\
\hline T3: Xenophobia (R) & 2419 & 0.27 & 0.11 & 0 & 1 & 1 \\
\hline T4: Right-wing extremists (R) & 2419 & 0.25 & 0.05 & 0 & 0 & 0 \\
\hline $\begin{array}{l}\text { Party preferences } \\
\text { (n) }\end{array}$ & 3287 & $\begin{array}{l}\text { cdu }=755, \text { fdp }=82, \text { gruene }=140, \text { linke }=144, \text { none } \\
=1532, \text { other.parties }=22, \text { spd }=612\end{array}$ & & & & \\
\hline Topic assignment (L) & 2307 & $1=565,2=671,3=681,4=390$ & & & & \\
\hline Topic assignment (R) & 2419 & $1=545,2=625,3=835,4=414$ & & & & \\
\hline
\end{tabular}


Fig. 14: Words that are associated with "left" and "right" (size $\propto$ wordcount)

Words that are associated with "left"

\title{
gerechtigkeit links kommunismus
}

sozialismus ddrkommunisten SOZIa

\author{
linken spd gegenteil menschen lafontaine \\ link sozialer umverteilung mehr \\ linke pds theichmacherei punks gysi

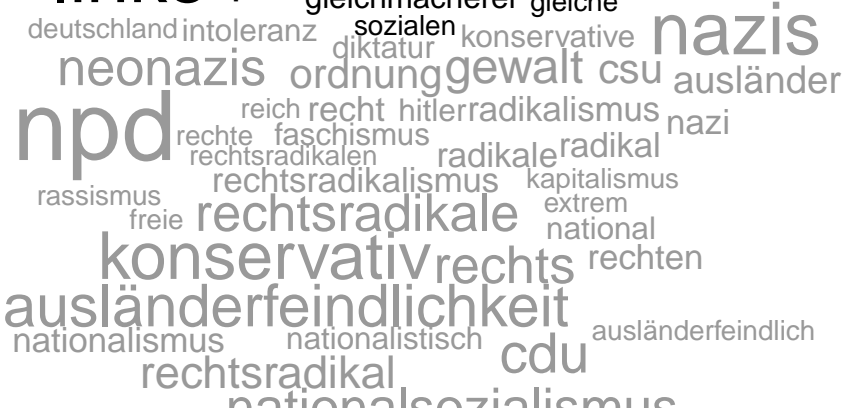

Words that are associated with "right" 
Fig. 15: Words that are associated with "left" by individuals of different self-reported left-right position (size $\propto$ wordcount)

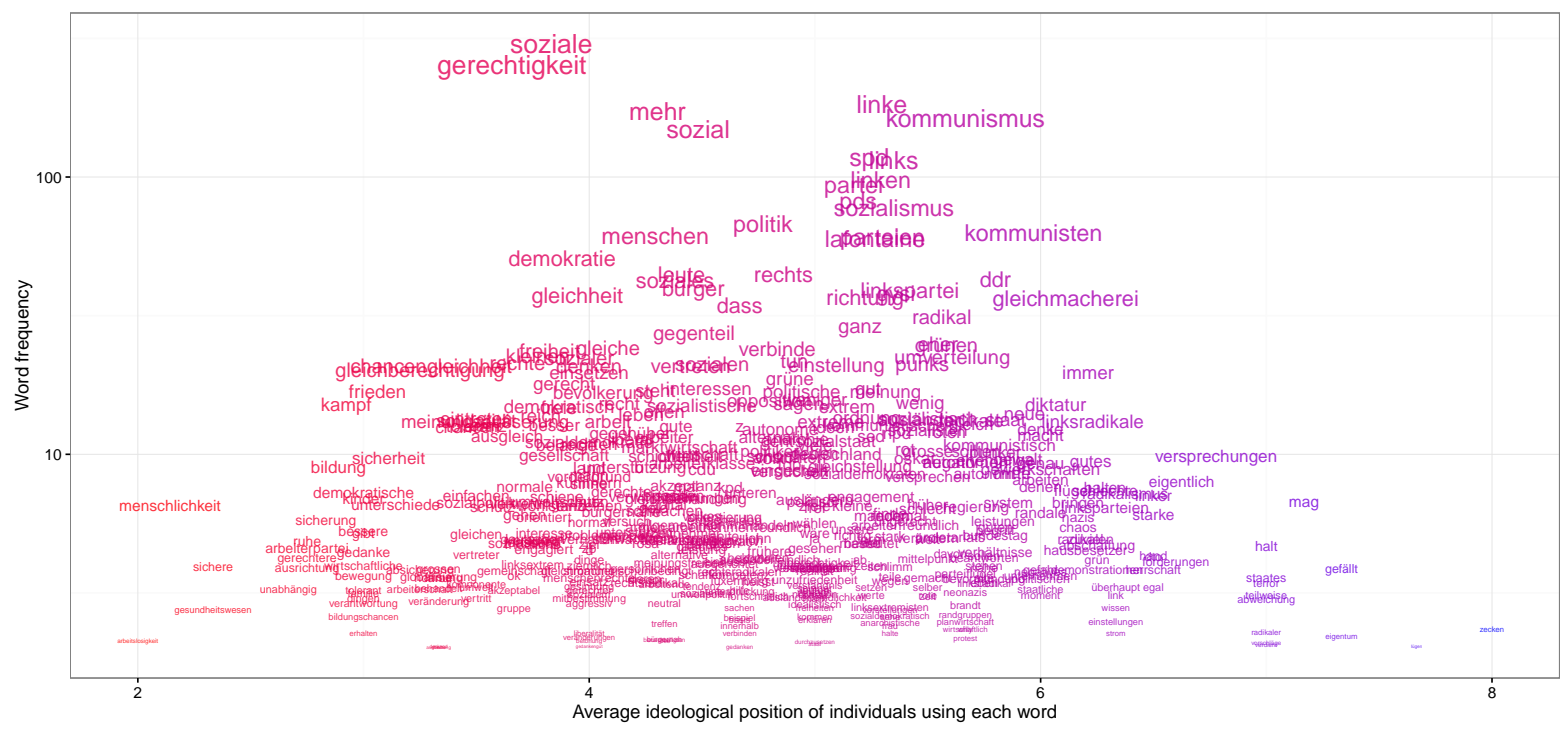

Fig. 16: Words that are associated with "right" by individuals of different self-reported left-right position (size $\propto$ wordcount)

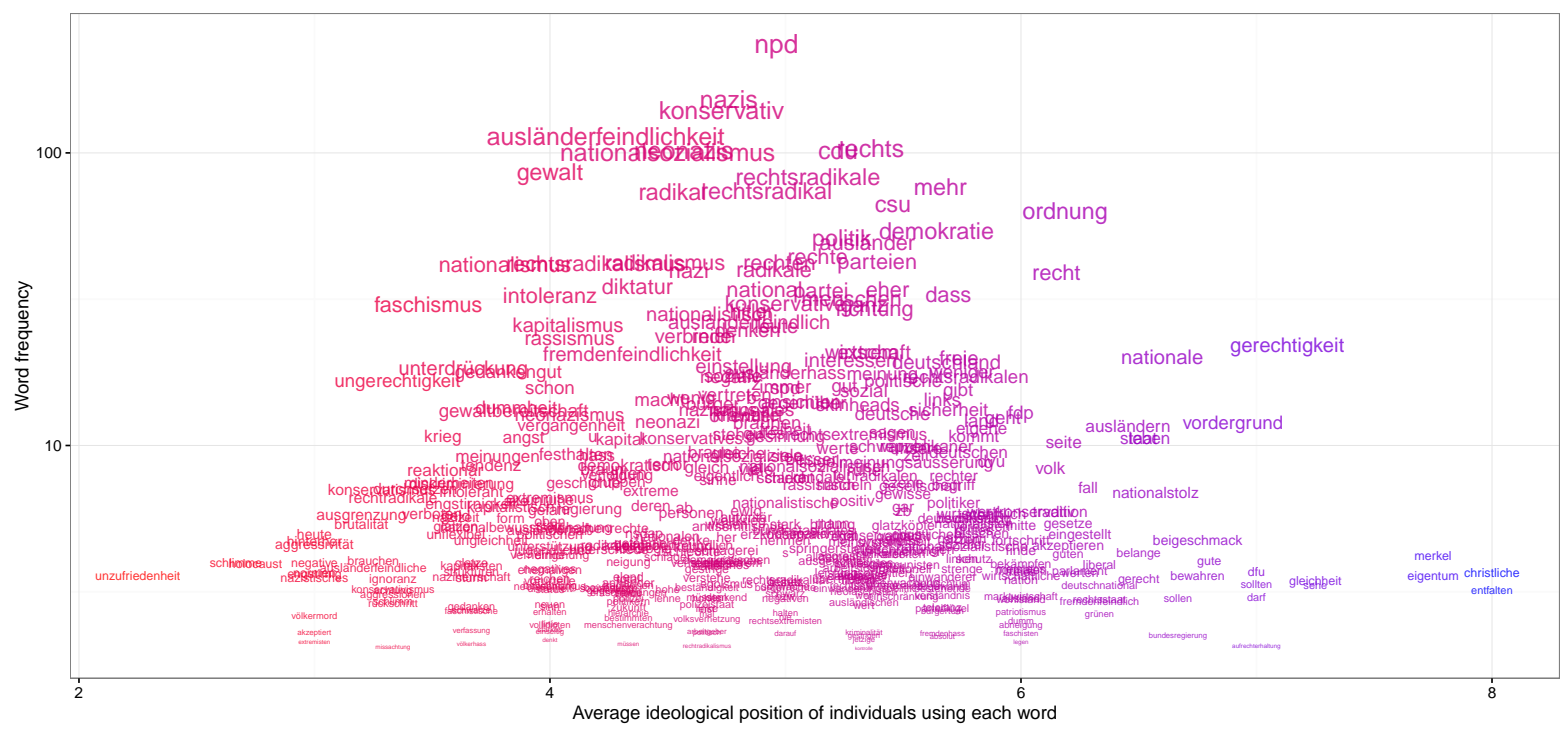


Table 4: Top 10 words that self-reported left- and right-wing individuals use to define "left" and "right"

\begin{tabular}{|c|c|c|c|c|c|c|c|}
\hline \multicolumn{4}{|c|}{ Concept: "left" } & \multicolumn{4}{|c|}{ Concept: "right" } \\
\hline word & LR & word & LR & word & LR & word & LR \\
\hline humanity & 2.1 & leftparties & 6.3 & brutality & 3.2 & laws & 6.2 \\
\hline protection & 2.8 & bad & 6.3 & ostracism & 3.2 & definitly & 6.3 \\
\hline education & 2.9 & radicalism & 6.4 & conservatism & 3.3 & foreigners & 6.5 \\
\hline fight & 2.9 & more left & 6.5 & right-wing extremists & 3.3 & state & 6.5 \\
\hline democratic & 3 & strong & 6.5 & injustice & 3.4 & live & 6.5 \\
\hline children & 3 & demands & 6.6 & enforce & 3.4 & national pride & 6.6 \\
\hline better & 3 & actually & 6.6 & facism & 3.5 & national & 6.6 \\
\hline exists & 3 & promises & 6.8 & illegal & 3.5 & good & 6.8 \\
\hline peace & 3.1 & halt (mostly filling word) & 7 & war & 3.5 & foreground & 6.9 \\
\hline security & 3.1 & like & 7.2 & reactionist & 3.6 & justice & 7.1 \\
\hline
\end{tabular}

Note: $L R$ corresponds to the average left-right position of individuals who mentioned this word in their responses about the meaning they attribute to "left" and "right". Only words used by 5 or more respondents are included in this analysis. Stopwords are excluded.

Table 5: Linear regression of left-right scale measurement values on topics of associations

\begin{tabular}{|c|c|c|}
\hline & \multicolumn{2}{|c|}{ Dependent variable: } \\
\hline & \multicolumn{2}{|c|}{ Left-right scale } \\
\hline & (1) & (2) \\
\hline Ideologies (L) & $\begin{array}{l}0.70^{* * *} \\
(0.09)\end{array}$ & \\
\hline Parties (L) & $\begin{array}{c}0.72^{* * *} \\
(0.10)\end{array}$ & \\
\hline Policies (L) & $\begin{array}{l}0.51^{* * * *} \\
(0.11)\end{array}$ & \\
\hline Parties (R) & & $\begin{array}{l}0.28^{* * * *} \\
(0.10)\end{array}$ \\
\hline Ideologies (R) & & $\begin{array}{c}0.06 \\
(0.09)\end{array}$ \\
\hline Xenophobia (R) & & $\begin{array}{l}-0.07 \\
(0.11)\end{array}$ \\
\hline Male & $\begin{array}{l}0.13^{*} \\
(0.07)\end{array}$ & $\begin{array}{l}0.18^{* *} \\
(0.07)\end{array}$ \\
\hline Age & $\begin{array}{c}0.04 \\
(0.03)\end{array}$ & $\begin{array}{c}0.02 \\
(0.03)\end{array}$ \\
\hline Education & $\begin{array}{l}-0.10^{*} \\
(0.05)\end{array}$ & $\begin{array}{c}-0.12^{* *} \\
(0.05)\end{array}$ \\
\hline Income & $\begin{array}{l}0.11^{* *} \\
(0.04)\end{array}$ & $\begin{array}{l}0.10^{* *} \\
(0.04)\end{array}$ \\
\hline Pol interest & $\begin{array}{l}-0.07 \\
(0.05)\end{array}$ & $\begin{array}{c}-0.11^{* *} \\
(0.05)\end{array}$ \\
\hline East & $\begin{array}{c}-0.37^{* * *} \\
(0.08)\end{array}$ & $\begin{array}{c}-0.33^{* * * *} \\
(0.08)\end{array}$ \\
\hline FDP & $\begin{array}{c}-0.49^{* *} \\
(0.21)\end{array}$ & $\begin{array}{c}-0.52^{* *} \\
(0.21)\end{array}$ \\
\hline Gruene & $\begin{array}{c}-2.14^{* * * *} \\
(0.16)\end{array}$ & $\begin{array}{c}-2.36^{* * * *} \\
(0.16)\end{array}$ \\
\hline Linke & $\begin{array}{c}-2.81^{* * * *} \\
(0.17)\end{array}$ & $\begin{array}{c}-3.23^{* * *} \\
(0.16)\end{array}$ \\
\hline None & $\begin{array}{c}-1.14^{* * * *} \\
(0.09)\end{array}$ & $\begin{array}{c}-1.29^{* * * *} \\
(0.09)\end{array}$ \\
\hline Other parties & $\begin{array}{c}-0.78^{*} \\
(0.47)\end{array}$ & $\begin{array}{l}-0.52 \\
(0.45)\end{array}$ \\
\hline SPD & $\begin{array}{c}-1.83^{* * * *} \\
(0.10)\end{array}$ & $\begin{array}{c}-1.91^{* * *} \\
(0.10)\end{array}$ \\
\hline Constant & $\begin{array}{c}5.68^{* * * *} \\
(0.15) \\
\end{array}$ & $\begin{array}{c}6.26^{* * * *} \\
(0.14) \\
\end{array}$ \\
\hline Observations & 1,946 & 2,007 \\
\hline $\mathrm{R}^{2}$ & 0.32 & 0.31 \\
\hline Adjusted $\mathrm{R}^{2}$ & 0.32 & 0.30 \\
\hline
\end{tabular}


Table 6: Linear regression of left-right scale measurement values on topics of associations (controlling for associations with right)

\begin{tabular}{|c|c|c|c|c|}
\hline & \multicolumn{4}{|c|}{ Dependent variable: } \\
\hline & \multicolumn{4}{|c|}{ Left-right scale } \\
\hline & $\begin{array}{l}\text { Subsample: Right- } \\
\text { wing extremists (R) }\end{array}$ & $\begin{array}{l}\text { Subsample: Parties } \\
\text { (R) }\end{array}$ & $\begin{array}{l}\text { Subsample: Ideolo- } \\
\text { gies (R) }\end{array}$ & $\begin{array}{l}\text { Subsample: Xeno- } \\
\text { phobia (R) }\end{array}$ \\
\hline & (1) & $(2)$ & (3) & (4) \\
\hline Ideologies (L) & $\begin{array}{l}0.85^{* * *} \\
(0.23)\end{array}$ & $\begin{array}{l}0.17 \\
(0.24)\end{array}$ & $\begin{array}{l}0.90^{* * *} \\
(0.15)\end{array}$ & $\begin{array}{l}0.64^{* * *} \\
(0.22)\end{array}$ \\
\hline Parties (L) & $\begin{array}{l}0.75^{* * *} \\
(0.21)\end{array}$ & $\begin{array}{l}0.37^{*} \\
(0.22)\end{array}$ & $\begin{array}{l}0.93^{* * * *} \\
(0.17)\end{array}$ & $\begin{array}{l}0.33 \\
(0.26)\end{array}$ \\
\hline Policies (L) & $\begin{array}{l}0.40^{*} \\
(0.24)\end{array}$ & $\begin{array}{l}0.16 \\
(0.28)\end{array}$ & $\begin{array}{l}0.59^{* * * *} \\
(0.18)\end{array}$ & $\begin{array}{l}0.28 \\
(0.23)\end{array}$ \\
\hline Male & $\begin{array}{l}0.10 \\
(0.16)\end{array}$ & $\begin{array}{l}0.07 \\
(0.16)\end{array}$ & $\begin{array}{l}0.10 \\
(0.13)\end{array}$ & $\begin{array}{l}0.37^{* *} \\
(0.17)\end{array}$ \\
\hline Age & $\begin{array}{l}0.01 \\
(0.07)\end{array}$ & $\begin{array}{l}0.01 \\
(0.07)\end{array}$ & $\begin{array}{l}0.09^{*} \\
(0.05)\end{array}$ & $\begin{array}{l}-0.04 \\
(0.07)\end{array}$ \\
\hline Education & $\begin{array}{l}-0.04 \\
(0.11)\end{array}$ & $\begin{array}{l}-0.18^{*} \\
(0.11)\end{array}$ & $\begin{array}{l}-0.03 \\
(0.09)\end{array}$ & $\begin{array}{l}-0.14 \\
(0.13)\end{array}$ \\
\hline Income & $\begin{array}{l}0.04 \\
(0.11)\end{array}$ & $\begin{array}{l}0.21^{* *} \\
(0.09)\end{array}$ & $\begin{array}{l}0.10 \\
(0.07)\end{array}$ & $\begin{array}{l}0.11 \\
(0.10)\end{array}$ \\
\hline Pol interest & $\begin{array}{l}0.05 \\
(0.12)\end{array}$ & $\begin{array}{l}-0.05 \\
(0.11)\end{array}$ & $\begin{array}{l}-0.08 \\
(0.09)\end{array}$ & $\begin{array}{l}-0.21 \\
(0.13)\end{array}$ \\
\hline East & $\begin{array}{l}-0.51^{* * * *} \\
(0.17)\end{array}$ & $\begin{array}{l}-0.27 \\
(0.17)\end{array}$ & $\begin{array}{l}-0.17 \\
(0.14)\end{array}$ & $\begin{array}{l}-0.18 \\
(0.18)\end{array}$ \\
\hline FDP & $\begin{array}{l}-0.39 \\
(0.44)\end{array}$ & $\begin{array}{l}-0.55 \\
(0.52)\end{array}$ & $\begin{array}{l}-0.60^{*} \\
(0.34)\end{array}$ & $\begin{array}{l}-0.11 \\
(0.48)\end{array}$ \\
\hline Gruene & $\begin{array}{l}-2.01^{* * * *} \\
(0.44)\end{array}$ & $\begin{array}{l}-2.18^{\text {**** }} \\
(0.37)\end{array}$ & $\begin{array}{l}-2.24^{* * * *} \\
(0.24)\end{array}$ & $\begin{array}{l}-2.24^{* * * *} \\
(0.39)\end{array}$ \\
\hline Linke & $\begin{array}{l}-2.53^{* * *} \\
(0.35)\end{array}$ & $\begin{array}{l}-3.03^{* * *} \\
(0.37)\end{array}$ & $\begin{array}{l}-3.08^{* * *} \\
(0.30)\end{array}$ & $\begin{array}{l}-2.88^{* * *} \\
(0.36)\end{array}$ \\
\hline None & $\begin{array}{l}-0.77^{* * * *} \\
(0.20)\end{array}$ & $\begin{array}{l}-1.30^{* * * *} \\
(0.19)\end{array}$ & $\begin{array}{l}-1.40^{* * * *} \\
(0.17)\end{array}$ & $\begin{array}{l}-1.24^{* * *} \\
(0.25)\end{array}$ \\
\hline Other parties & $\begin{array}{l}2.91^{* *} \\
(1.44)\end{array}$ & $\begin{array}{l}-1.56^{* *} \\
(0.69)\end{array}$ & $\begin{array}{l}-2.47^{* * *} \\
(0.84)\end{array}$ & \\
\hline SPD & $\begin{array}{l}-1.38^{* * *} \\
(0.23)\end{array}$ & $\begin{array}{l}-1.87^{* * * *} \\
(0.21)\end{array}$ & $\begin{array}{l}-2.23^{* * *} \\
(0.18)\end{array}$ & $\begin{array}{l}-1.58^{* * *} \\
(0.26)\end{array}$ \\
\hline Constant & $\begin{array}{l}5.19^{* * * *} \\
(0.34) \\
\end{array}$ & $\begin{array}{l}6.23^{* * *} \\
(0.34) \\
\end{array}$ & $\begin{array}{l}5.60^{* * * *} \\
(0.27) \\
\end{array}$ & $\begin{array}{l}5.80^{* * * *} \\
(0.36) \\
\end{array}$ \\
\hline Observations & 370 & 446 & 618 & 307 \\
\hline $\mathrm{R}^{2}$ & 0.31 & 0.32 & 0.39 & 0.38 \\
\hline Adjusted $\mathrm{R}^{2}$ & 0.28 & 0.29 & 0.37 & 0.35 \\
\hline
\end{tabular}

Note: ${ }^{*} \mathrm{p}<0.1 ;{ }^{* *} \mathrm{p}<0.05 ;{ }^{* * *} \mathrm{p}<0.01 ;$ Estimation using OLS; Dependent variable: Left-right scale; 
Table 7: Linear regression of left-right scale measurement values on topics of associations (controlling for associations with left)

\begin{tabular}{|c|c|c|c|c|c|}
\hline & \multicolumn{5}{|c|}{ Dependent variable: } \\
\hline & \multicolumn{5}{|c|}{ Left-right scale } \\
\hline & $\begin{array}{l}\text { Subsample: Values } \\
\text { (L) }\end{array}$ & $\begin{array}{l}\text { Subsample: Ideolo- } \\
\text { gies (L) }\end{array}$ & $\begin{array}{l}\text { Subsample: Parties } \\
\text { (L) }\end{array}$ & $\begin{array}{l}\text { Subsample: } \\
\text { cies (L) }\end{array}$ & Poli- \\
\hline & (1) & $(2)$ & (3) & (4) & \\
\hline Parties (R) & $\begin{array}{l}0.57^{* *} \\
(0.22)\end{array}$ & $\begin{array}{l}-0.03 \\
(0.20)\end{array}$ & $\begin{array}{l}0.32^{*} \\
(0.17)\end{array}$ & $\begin{array}{l}0.33 \\
(0.27)\end{array}$ & \\
\hline Ideologies (R) & $\begin{array}{l}0.04 \\
(0.18)\end{array}$ & $\begin{array}{l}0.14 \\
(0.18)\end{array}$ & $\begin{array}{l}0.31 \\
(0.19)\end{array}$ & $\begin{array}{l}0.18 \\
(0.23)\end{array}$ & \\
\hline Xenophobia (R) & $\begin{array}{l}0.05 \\
(0.20)\end{array}$ & $\begin{array}{l}-0.02 \\
(0.22)\end{array}$ & $\begin{array}{l}-0.25 \\
(0.26)\end{array}$ & $\begin{array}{l}0.04 \\
(0.26)\end{array}$ & \\
\hline Male & $\begin{array}{l}0.16 \\
(0.14)\end{array}$ & $\begin{array}{l}0.22 \\
(0.15)\end{array}$ & $\begin{array}{l}-0.03 \\
(0.15)\end{array}$ & $\begin{array}{l}0.28 \\
(0.19)\end{array}$ & \\
\hline Age & $\begin{array}{l}-0.12^{*} \\
(0.06)\end{array}$ & $\begin{array}{l}0.09 \\
(0.06)\end{array}$ & $\begin{array}{l}0.06 \\
(0.06)\end{array}$ & $\begin{array}{l}0.08 \\
(0.08)\end{array}$ & \\
\hline Education & $\begin{array}{l}-0.01 \\
(0.10)\end{array}$ & $\begin{array}{l}-0.11 \\
(0.10)\end{array}$ & $\begin{array}{l}-0.04 \\
(0.11)\end{array}$ & $\begin{array}{l}-0.33^{* * * *} \\
(0.12)\end{array}$ & \\
\hline Income & $\begin{array}{l}0.11 \\
(0.08)\end{array}$ & $\begin{array}{l}0.10 \\
(0.09)\end{array}$ & $\begin{array}{l}0.10 \\
(0.09)\end{array}$ & $\begin{array}{l}0.18 \\
(0.11)\end{array}$ & \\
\hline Pol interest & $\begin{array}{l}-0.14 \\
(0.10)\end{array}$ & $\begin{array}{l}0.01 \\
(0.11)\end{array}$ & $\begin{array}{l}-0.01 \\
(0.10)\end{array}$ & $\begin{array}{l}-0.26^{*} \\
(0.14)\end{array}$ & \\
\hline East & $\begin{array}{l}-0.13 \\
(0.15)\end{array}$ & $\begin{array}{l}-0.19 \\
(0.17)\end{array}$ & $\begin{array}{l}-0.29^{*} \\
(0.15)\end{array}$ & $\begin{array}{l}-0.54^{* * *} \\
(0.20)\end{array}$ & \\
\hline FDP & $\begin{array}{l}-0.19 \\
(0.63)\end{array}$ & $\begin{array}{l}-0.55^{*} \\
(0.33)\end{array}$ & $\begin{array}{l}-0.56 \\
(0.43)\end{array}$ & $\begin{array}{l}-0.19 \\
(0.50)\end{array}$ & \\
\hline Gruene & $\begin{array}{l}-2.52^{* * *} \\
(0.30)\end{array}$ & $\begin{array}{l}-1.98^{* * * *} \\
(0.32)\end{array}$ & $\begin{array}{l}-2.21^{* * * *} \\
(0.41)\end{array}$ & $\begin{array}{l}-1.91^{* * * *} \\
(0.36)\end{array}$ & \\
\hline Linke & $\begin{array}{l}-3.14^{* * *} \\
(0.28)\end{array}$ & $\begin{array}{l}-2.75^{* * *} \\
(0.48)\end{array}$ & $\begin{array}{l}-3.33^{* * *} \\
(0.41)\end{array}$ & $\begin{array}{l}-2.34^{* * *} \\
(0.40)\end{array}$ & \\
\hline None & $\begin{array}{l}-1.55^{* * *} \\
(0.24)\end{array}$ & $\begin{array}{l}-1.43^{* * *} \\
(0.18)\end{array}$ & $\begin{array}{l}-0.90^{* * *} \\
(0.17)\end{array}$ & $\begin{array}{l}-1.13^{* * *} \\
(0.25)\end{array}$ & \\
\hline Other parties & $\begin{array}{l}-2.59^{*} \\
(1.34)\end{array}$ & $\begin{array}{l}-1.27^{*} \\
(0.75)\end{array}$ & $\begin{array}{l}-1.40 \\
(1.50)\end{array}$ & $\begin{array}{l}-1.01 \\
(0.87)\end{array}$ & \\
\hline SPD & $\begin{array}{l}-1.98^{* * *} \\
(0.25)\end{array}$ & $\begin{array}{l}-1.86^{* * *} \\
(0.18)\end{array}$ & $\begin{array}{l}-1.87^{* * * *} \\
(0.22)\end{array}$ & $\begin{array}{l}-1.77^{* * * *} \\
(0.27)\end{array}$ & \\
\hline Constant & $\begin{array}{l}5.98^{* * * *} \\
(0.32) \\
\end{array}$ & $\begin{array}{l}6.14^{* * * *} \\
(0.28) \\
\end{array}$ & $\begin{array}{l}6.02^{* * * *} \\
(0.27) \\
\end{array}$ & $\begin{array}{l}6.18^{* * *} \\
(0.36) \\
\end{array}$ & \\
\hline Observations & 437 & 506 & 505 & 293 & \\
\hline $\mathrm{R}^{2}$ & 0.31 & 0.28 & 0.26 & 0.33 & \\
\hline Adjusted $\mathrm{R}^{2}$ & 0.29 & 0.26 & 0.23 & 0.30 & \\
\hline
\end{tabular}

Note: ${ }^{*} \mathrm{p}<0.1 ;{ }^{* *} \mathrm{p}<0.05 ;{ }^{* * *} \mathrm{p}<0.01$; Estimation using OLS; Dependent variable: Left-right scale;

Acknowledgements ... 


\section{References}

Aldrich JH, McKelvey RD (1977) A method of scaling with applications to the 1968 and 1972 presidential elections. American Political Science Review 71(1):111-130

Alwin DF, Krosnick JA (1991) The reliability of survey attitude measurement the influence of question and respondent attributes. Sociological Methods \& Research 20(1):139-181

Bafumi J, Herron MC (2010) Leapfrog representation and extremism: A study of american voters and their members in congress. American Political Science Review 104(3):519-542

Bakker R, Edwards E, Jolly S, Polk J, Rovny J, Steenbergen M (2014a) Anchoring the experts: Using vignettes to compare party ideology across countries. Research \& Politics 1(3), DOI 2053168014553502

Bakker R, Jolly S, Polk J, Poole K (2014b) The european common space: Extending the use of anchoring vignettes. The Journal of Politics 76(4):1089-1101

Bauer-Kaase P (2001) Politische ideologie im wandel? eine längsschnittanalyse der inhalte der politischen richtungsbegriffe "links" und "rechts". In: Klingemann HD, Kaase M (eds) Wahlen und Wähler Analysen aus Anlass der Bundestagswahl 1998, Westdeutscher Verlag, Wiesbaden, pp 207-243

Belson WA (1981) The design and understanding of survey questions. Gower, Aldershot

Blei DM, Ng AY, Jordan MI (2003) Latent dirichlet allocation. The Journal of Machine Learning Research 3:993-1022

Bonica A (2013) Ideology and interests in the political marketplace. American Journal of Political Science 57(2):294-311

Brady HE (1985) The perils of survey research: Inter-personally incomparable responses. Political Methodology 11(3/4):269-291

Bratton M (2010) Anchoring the 'd-word' in comparative survey research. Journal of Democracy 21(4):106-113

Bratton M, Mattes RB, Gyimah-Boadi E (2004) Public opinion, democracy, and market reform in Africa. Cambridge University Press, Cambridge

Braun M, Behr D, Kaczmirek L (2013) Assessing cross-national equivalence of measures of xenophobia: Evidence from probing in web surveys. International Journal of Public Opinion Research 25(3):383-395

Campbell A, Converse PE, Miller WE, Donald E (1960) The American Voter. Wiley, New York

Canache D, Mondak JJ, Seligson MA (2001) Meaning and measurement in cross-national research on satisfaction with democracy. Public Opinion Quarterly 65(4):506-528

Conover PJ, Feldman S (1981) The origins and meaning of liberal/conservative self-identifications. American Journal of Political Science 25(4):617-645

Converse PE (1964) The nature of belief system in mass publics. In: Apter DE (ed) Ideology and Discontent, The Free Press, New York, pp 206-261

Corbetta P, Cavazza N, Roccato M (2009) Between ideology and social representations: Four theses plus (a new) one on the relevance and the meaning of the political left and right. European Journal of Political Research 48(5):622-641

Dalton RJ, Sin DC, Jou W (2007) Understanding democracy: Data from unlikely places. Journal of Democracy 18(4):142-156

Downs A (1957) An Economic Theory of Democracy. Harper \& Row, New York

Dunn K (2011) Left-right identification and education in europe: A contingent relationship. Comparative European Politics 9(3):292-316

Eisenstein J, Ahmed A, Xing EP (2011) Sparse additive generative models of text. In: Proceedings of the 28th International Conference on Machine Learning (ICML-11), pp 1041-1048

Ekehammar B, Nilsson I, Sidanius J (1987) Education and ideology: Basic aspects of education related to adolescents' sociopolitical attitudes. Political Psychology 8(3):395-410

Everett JA (2013) The 12 item social and economic conservatism scale (secs). PloS one 8(12), DOI 10.1371/journal.pone.0082131

Fitzgerald J (2013) What does 'political' mean to you? Political Behavior 35(3):453-479

Fitzgerald R, Widdop S, Gray M, Collins D (2011) Identifying sources of error in cross-national questionnaires: application of an error source typology to cognitive interview data. Journal of Official Statistics 27(4):569-599

Freire A (2006) Bringing social identities back in: The social anchors of left-right orientation in western europe. International Political Science Review 27(4):359-378

Freire A, Belchior AM (2011) What left and right means to portuguese citizens. Comparative European Politics 9(2):145-167

Fuchs D, Klingemann HD (1989) Das links-rechts-schema als politischer code. ein interkultureller vergleich auf inhaltsanalytischer grundlage. In: Haller M, Hoffmann-Nowotny HJ, Zapf W (eds) Kultur und Gesellschaft: Verhandlungen des 24. Deutschen Soziologentags, des 11. Österreichischen Soziologentags und des 8. Kongresses der Schweizerischen Gesellschaft für Soziologie in Zürich 1988, Campus Verlag, Frankfurt am Main, pp 484-498

Fuchs D, Klingemann HD (1990) The left-right schema. In: Jennings MK, van Deth JW (eds) Continuities in political action: A longitudinal study of political orientations in three western democracies, de Gruyter, Berlin, pp 203-234

Fuhse JA (2004) Links oder rechts oder ganz woanders? zur konstruktion der politischen landschaft. Österreichische Zeitschrift für Politikwissenschaft 33(2):209-226

Gabennesch H (1972) Authoritarianism as world view. American Journal of Sociology 77(5):857-875

Gerber AS, Huber GA, Doherty D, Dowling CM, Ha SE (2010) Personality and political attitudes: Relationships across issue domains and political contexts. American Political Science Review 104(1):111-133

GESIS - Leibniz Institute for the Social Sciences (2011): ALLBUS/GGSS 2008 (Allgemeine Bevölkerungsumfrage der Sozialwissenschaften/German General Social Survey 2008). GESIS Data Archive, Cologne. ZA4600 Data file Version 2.0.0.

GESIS - Leibniz Institute for the Social Sciences (2009): ALLBUS/GGSS 2008 (Allgemeine Bevölkerungsumfrage der Sozialwissenschaften/German General Social Survey 2008): Open answers to the questions on associations with the terms "left" and "right". GESIS Data Archive, Cologne. ZA4605 Data file Version 1.0.0. doi:10.4232/1.11485

Groves RM (1989) Survey errors and survey costs. Wiley, New York

Hare C, Armstrong DA, Bakker R, Carroll R, Poole KT (2015) Using bayesian Aldrich-McKelvey scaling to study citizens' ideological preferences and perceptions. American Journal of Political Science 59(3):759-774

Hochschild JL (1986) What's fair: American beliefs about distributive justice. Harvard University Press, Cambridge

Hotelling H (1929) Stability in competition. The Economic Journal 39(153):41-57

Huber JD (1989) Values and partisanship in left-right orientations: measuring ideology. European Journal of Political Research 17(5):599621 
Inglehart R, Klingemann HD (1976) Party identification, ideological preference and left-right dimension among western mass publics. In: Budge I, Crewe I, Farlie DJ (eds) Party Identification and Beyond: Representations of Voting and Party Competition, John Wiley \& Sons, London, pp 243-273

Jaccard J, Jacoby J (2010) Theory construction and model-building skills: A practical guide for social scientists. Guilford Press, New York Jahn D (2011) Conceptualizing left and right in comparative politics towards a deductive approach. Party Politics 17(6):745-765

Jessee SA (2009) Spatial voting in the 2004 presidential election. American Political Science Review 103(01):59-81

Kaiser FM, Lilly JR (1975) Political attitudes among students: A small college experience. Adolescence 10(38):287-295

King G, Wand J (2007) Comparing incomparable survey responses: Evaluating and selecting anchoring vignettes. Political Analysis 15(1):46-66

King G, Murray CJ, Salomon JA, Tandon A (2004a) Enhancing the validity and cross-cultural comparability of measurement in survey research. American Political Science Review 98(1):191-207

King G, Murray CJL, Salomon JA, Tandon A (2004b) Enhancing the validity and cross-cultural comparability of measurement in survey research. The American Political Science Review 98(1):191-207

Kitschelt H (2004) Diversification and reconfiguration of party systems in postindustrial democracies. Internationale Politikanalyse, Friedrich-Ebert-Stiftung

Kitschelt H, Hellemans S (1990) The left-right semantics and the new politics cleavage. Comparative Political Studies 23(2):210-238

Klingemann HD (1972) Testing the left-right continuum on a sample of german voters. Comparative Political Studies 5(1):93-106

Klingemann HD (1979) Measuring ideological conceptualizations. In: Barnes SH, Kaase M, Allerback KR, Klingemann HD, Marsh A, Rosenmayr L (eds) Political Action: Mass Participation in Five Western Democracies, Sage, Beverly Hills, CA, pp 215-254

Klingemann HD, Wright WE (1973) Dimensions of political belief systems:'levels of conceptualization as a variable. some results for usa and frg 1968/69. Comparative Political Studies 5:93-106

Knutsen O (1995) Value orientations, political conflicts and left-right identification: A comparative study. European Journal of Political Research 28(1):63-93

Kosinski M, Stillwell D, Graepel T (2013) Private traits and attributes are predictable from digital records of human behavior. Proceedings of the National Academy of Sciences 110(15):5802-5805

Krosnick JA (1991) Response strategies for coping with the cognitive demands of attitude measures in surveys. Applied cognitive psychology 5(3):213-236

Leonisio R, Strijbis O (2014) Beyond self-placement: Why nationalism is a better predictor of electoral behaviour in the basque country. Revista Española de Investigaciones Sociológicas 146:47-68

McClintock CG, Turner HA (1962) The impact of college upon political knowledge, participation, and values. Human Relations 15(2):163-176

Meisenberg G, Williams A (2008) Are acquiescent and extreme response styles related to low intelligence and education? Personality and Individual Differences 44(7):1539-1550

Morton R, Tyran JR, Wengström E (2011) Income and ideology: How personality traits, cognitive abilities, and education shape political attitudes. University of Copenhagen Dept of Economics Discussion Paper

Neundorf A (2009) Growing up on different sides of the wall-a quasi-experimental test: Applying the left-right dimension to the german mass public. German Politics 18(2):201-225

Neundorf A (2011) Die links-rechts-dimension auf dem prüfstand: Ideologisches wählen in ost-und westdeutschland 1990-2008. Politische Vierteljahresschrift 45:227-250

Piurko Y, Schwartz SH, Davidov E (2011) Basic personal values and the meaning of left-right political orientations in 20 countries. Political Psychology 32(4):537-561

Poole KT (1998) Recovering a basic space from a set of issue scales. American Journal of Political Science 42(3):954-993

Poole KT, Rosenthal H (2007) Ideology and Congress. Transaction Publishers, Piscataway

Raschke J (1998) Die erfindung von links/rechts als politisches richtungsschema. In: Greven MT, Münkler H, Schmalz-Bruns R (eds) Bürgersinn und Kritik, Nomos, Baden-Baden, pp 185-206

Roberts ME, Stewart BM, Tingley D (2014a) stm: R Package for Structural Topic Models. R package version 0.6.1

Roberts ME, Stewart BM, Tingley D, Lucas C, Leder-Luis J, Gadarian SK, Albertson B, Rand DG (2014b) Structural topic models for open-ended survey responses. American Journal of Political Science 58:1064-1082

Rosenberg M (1956) Misanthropy and political ideology. American Sociological Review 21(6):690-695

Rudi T (2010) Die links-rechts-dimension in mittel-und osteuropa: "super-issue" oder bedeutungslos? In: Faas T, Arzheimer K, Siegried R (eds) Information-Wahrnehmung-Emotion, VS Verlag für Sozialwissenschaften, pp 169-189

Schmitt H, van der Eijk C (2009) On the changing and variable meaning of left and right. In: Working Paper

Scholz E, Züll C (2012) Item non-response in open-ended questions: Who does not answer on the meaning of left and right? Social Science Research 41(6):1415-1428

Stokes DE (1963) Spatial models of party competition. The American Political Science Review 57(2):368-377

Sturgis P, Smith P (2010) Assessing the validity of generalized trust questions: What kind of trust are we measuring? International Journal of Public Opinion Research 22(1):74-92

Taddy M (2013) Multinomial inverse regression for text analysis. Journal of the American Statistical Association 108(503):755-770

Tourangeau R, Rips LJ, Rasinski K (2000) The Psychology of Survey Response. Cambridge University Press, Cambridge, UK

Uslaner EM (2002) The Moral Foundations of Trust. Cambridge University Press, Cambridge, United Kingdom

Vries CEd, Hakhverdian A, Lancee B (2013) The dynamics of voters' left/right identification: The role of economic and cultural attitudes. Political Science Research and Methods 1(2):223-238

Weber W (2011) Testing for measurement equivalence of individuals' left-right orientation. Survey Research Methods 5(1):1-10

Weil FD (1985) The variable effects of education on liberal attitudes: A comparative-historical analysis of anti-semitism using public opinion survey data. American Sociological Review pp 458-474

Zaller JR (1992) The Nature and Origins of Mass Opinion. Cambridge University Press, Cambridge

Zechmeister E (2006) What's left and who's right? a q-method study of individual and contextual influences on the meaning of ideological labels. Political Behavior 28(2):151-173

Zechmeister E, Corral M (2010) The varying economic meaning of 'left' and 'right' in latin america. AmericasBarometer Insights Series 38:1-10 
Züll C, Scholz E (2012) Assoziationen mit den politischen Richtungsbegriff en "links" und "rechts" im internationalen Vergleich: Kategorienschema für die Codierung offener Angaben. GESIS

Züll C, Scholz E, Schmitt H (2010) Kategorienschema für die Vercodung von Assoziationen mit den politischen Richtungsbegriffen" links" und" rechts". GESIS 